\title{
LA MASA Y EL PUBLICO* \\ Una investigación metodológica y sociológica
}

\section{Robert E. Park}

\section{Capítulo I. La masa}

I. El origen y la situación actual de la psicología de masas.-II. La concepción de la psicología de masas de Sighele y su concepto de masa.- III. La definición de la masa por parte de Le Bon y el concepto de alma colectiva. Pasquale Rossi.-IV. Las llamadas propiedades de la masa.-V. La masa como unidad real.-VI. Dificultades de esta concepción. La sustancialidad de la masa.

\section{Capítulo II. El proceso sociológico}

I. La sociología como ciencia de la naturaleza; las dificultades lógicas en la construcción de conceptos sociológicos. El elemento sociológico. La economía política y la psicología de las masas. La teoría de la imitación.-II. Los predecesores de la teoría de la imitación: Butler, Hume, Adam Smith. Dos conceptos diferentes de la simpatía.-III. La imitación considerada a) como proceso sociológico, b) como medio de transmisión de la tradición, c) como la forma en que la totalidad ejerce presión sobre el individuo.-IV. El concepto de imitación según Tarde y según Baldwin. La imitación en la masa considerada como un tipo de atención sociológica. Las diversas formas en que se manifiesta la atención sociológica. La imitación como un proceso de represión.-V. La masa y el público. El público como confluencia de opiniones opuestas. El concepto de la oposición sociológica. Las formaciones (constructos) sociales que se consideran como productos de esos procesos. La conciencia normativa del público y la voluntad general.

* Versión del original alemán de la tesis doctoral de PARK, publicada como Masse und Publikum: Eine methodologische und soziologische Untersuchung (Berna, Buchdruckerei Lack und Grunau, 1904). Existe una versión inglesa editada por Henry Elsner Jr. y traducida por Charlotte Elsner: The Crowd and the Public and other Essays, Chicago, Chicago University Press, 1972, que ha sido tenida en cuenta aunque muestra significativas omisiones e insuficiencias). 


\section{Capítulo III. La voluntad general}

I. El concepto de voluntad general en su desarrollo histórico: Hobbes y Locke, Rousseau, Kant, Fichte, Hegel. La voluntad general y la psicología social.-II. Las características psicológicas de los grupos sociales. La diferencia y la posición de la masa y del público respecto a otros tipos de grupos. Las diferencias entre ambos.

\section{CAPITULO I}

\section{LA MASA}

El grupo social es uno de los más fecundos objetos de consideración científica que han surgido en los estudios recientes de psicología. Entre todas las diversas formas de agrupación que se dan en una vida social muy desarrollada como la nuestra, la masa — y sus diversos tipos - es la que ha atraído más la atención de los sociólogos. A partir de este interés se desarrolló la psicología de la masa o de la colectividad, un campo que encuentra el prototipo de los grupos sociales en las formas de agrupación carentes de vinculación o desorganizadas, como los partidos políticos o cualquier aglomeración de una multitud humana.

La psicología de las masas es, por tanto, una novedad en el ámbito de la ciencia. Así se explica que, como ciencia nueva, si se le puede llamar así, se vea forzada a trabajar con nociones muy indeterminadas. Donde no existe una tradición científica previa, faltan necesariamente también las determinaciones exactas de las palabras que requieren sus objetos. La capacidad para diferenciar, definir e identificar los hechos con la que comienza cualquier ciencia, supone la existencia de una terminología más o menos establecida.

La defectuosa conceptualización con la que hay que contar para designar los fenómenos masivos, en el intento de determinarlos teóricamente, se pone de manifiesto sobre todo en el empleo de palabras como masa, pueblo (Volk), secta, y otras; palabras que se usan en el lenguaje ordinario para designar diferentes tipos de agrupación, y que están más o menos cargadas de juicios de valor de carácter ético o político de los que no se libran nunca, ni siquiera cuando se pretende usarlas en un sentido puramente teórico, como en el caso de la psicología de masas. Pero no es ésta la única manifestación de esa carencia. Tampoco en los distintos autores tienen dichas palabras el mismo significado. E incluso, algunas veces, un mismo autor las emplea en diversos sentidos a lo largo del tiempo. Se produce una continua vacilación que depende de la imagen que en cada momento tenga ante sus ojos el autor de que se trate ${ }^{1}$.

${ }^{1}$ Compárese el uso de la palabra «masa» en el primer libro de Sighele, La coppia criminale, con su uso por parte del mismo autor en su último libro, La delinquenza settaria. En la primera obra la masa se identifica con la chusma; en el segundo, por el contrario, se entiende por masa un núcleo de organización social del que eventualmente pueden surgir otras formas. Véase la tra- 
Ahora bien, se puede creer, como piensa el autor, que todo avance esencial en sociología, en definitiva, debe proceder de investigaciones como las que ha iniciado la psicología de masas, es decir describiendo y explicando las actividades de la vida de los grupos humanos. El examen del material ya disponible y una definición más exacta de los conceptos relevantes aparece como algo no solamente deseable, sino necesario. Este trabajo se propone hacerlo respecto de dos formas básicas de las unidades sociales: la masa y el público.

\section{II}

El primer intento de definir la esencia de la masa con precisión científica parece ser el del Prof. Scipio Sighele, un criminólogo italiano. En 1891 publicó su obra La folla delinquente, un libro escrito bajo la plena inspiración de la escuela positivista de derecho penal y planteado como una contribución a la solución del problema de la responsabilidad individual y colectiva. Ciertamente, encontramos antes, en la literatura médico-jurídica, todo un conjunto de investigaciones sobre el fenómeno de las epidemias sociales, especialmente las epidemias de crímenes que se manifiestan con frecuencia abiertamente como casos de masas criminales. Por ejemplo, Tarde, en su libro Philosophie pénale, apunta claramente a la masa como un fenómeno social específico, merecedor de estudio científico ${ }^{2}$.

La significación de la obra de Sighele reside en su intento de reunir todas estas manifestaciones de epidemias sociales en un solo concepto que vino a facilitar extraordinariamente la investigación científica posterior. Como Sighele consideró el fenómeno de la masa desde el punto de vista propio de su escuela, tendió a considerar raro y anormal que individuos que usualmente no se rebelan contra las restricciones de la costumbre y del derecho, perdieran su estabilidad moral habitual y su autodominio bajo la influencia de la agitación de la masa y se comportaran como animales furiosos y no como seres humanos ${ }^{3}$.

La folla criminale de Sighele es, en parte, una descripción prolija y, en parte, una explicación de ese fenómeno general. Para este autor el carácter propio de la masa consiste en que no puede considerarse simplemente como la suma de sus partes. Es decir, el comportamiento del grupo como un todo es totalmente diferente del que cabría esperar de cada uno de sus miembros individuales si actuaran solos ${ }^{4}$.

No se puede tomar a los individuos unidos en una masa como aparecen a primera vista, como un simple agregado. La masa tiene que ser considerada,

ducción alemana hecha por vON KURELla del primer libro mencionado de Sighele, Psychologie des Auflaufs und der Massenverbrechen, pp. 40 ss, y del segundo una traducción francesa, Psychologie des sectes, p. 46. ${ }^{2}$ TARDE, Philosophie pénale, p. 320.

3 Sighele, Psychologie des Auflaufs und der Massenverbrechen, pp. 20 y ss.

${ }^{4}$ Sighele, Psychologie des Auflaufs und der Massenverbrechen, p. 44. 
dice Sighele, como algo determinado que se distingue de todos sus miembros particulares: se convierte manifiestamente en individuo. Por eso se puede hablar de un alma de las masas.

Vista desde fuera, la masa es una aglomeración desorganizada, compuesta por elementos heterogéneos y carente de sistema y de partes diferenciadas 5 . Pero lo más importante del fenómeno de la masa no es, de ningún modo, esa apariencia puramente externa, que es la más próxima a la perspectiva ordinaria. Lo que permite conocer mucho mejor la naturaleza propia del fenómeno de la masa son sus manifestaciones psicológicas. La solución del problema de la masa pasa por la investigación del alma de la masa. De modo que para Sighele y los demás miembros de su escuela, el problema de la masa es sociopsicológico. Esto significaba una ruptura total con los métodos de la escuela italiana del derecho positivo de la que procedían, porque la escuela italiana sólo fue capaz de intentar una explicación de la masa criminal sometiendo las características físicas y mentales de los individuos que la componen a investigaciones antropológicas ${ }^{6}$.

Ahora bien, puesto que se trata aquí de entender el alma de la masa, cabe preguntar si no resulta difícil obtener de Sighele y de los demás autores una respuesta no ambigua al respecto. Lo que dice Sighele del alma de la masa se puede sintetizar en este principio: en la masa, las capacidades individuales de los individuos se neutralizan mutuamente; por contra, su afectividad resulta recíprocamente reforzada, de tal modo que el todo se configura como una unidad dominada por un sentimiento cuya fuerza viene a ser equivalente a la suma de las intensidades de las emociones individuales?

5 Ibid., p. 24, y TARDE, Philosophie pénale, p. 320.

${ }^{6}$ Lombroso y Lasche, Der politische Verbrecher. Aunque la explicación de Sighele de la masa se guía por principios totalmente diferentes, sin embargo es interesante advertir que no consigue librarse de los viejos enfoques, pues asegura que no cabe una explicación completa de los fenómenos de las masas sin considerar los factores antropológicos. Véase Sighele, Massenauflauf, p. 74.

Sighele, Psychologie der Massenverbrechen, p. 201. «Desde un punto de vista moral el ser humano es un ser acumulativo; pero desde la perspectiva intelectual no lo es. Dicho de otro modo, así como las sensibilidades pueden sumarse, con respecto a los pensamientos sólo cabe la media aritmética. Por tanto, un centenar de hombres valientes forman un agregado heróicamente valiente, mientras que un centenar de hombres egregios se convierte en un grupo espiritualmente mediocre. Pero la cuestión de por qué las cualidades morales se comportan en las agrupaciones de un modo tan distinto que las intelectuales no queda respondida de este modo. Quisiera explicar esa realidad partiendo de que el espíritu y el talento no operan tan sugestivamente como lo hacen las sensibilidades y las emociones. Es muy correcto hablar del valor como de algo que se puede infundir: esto vale también para otros muchos dones y defectos de la vida afectiva: el miedo, el odio, la confianza, la simpatía pueden comunicarse precisamente porque se convierten en patrimonio del individuo por adquisición y no por herencia. Lo cual no ocurre con el talento y el espíritu; se nace o no se nace con ellos, pero no pueden adquirirse. Es verdad que las cualidades morales dependen más de la herencia que de la educación, como ha subrayado la escuela positivista de derecho penal; pero, no obstante, y dejando aparte las excepciones, siempre es más fácil formar mediante la educación y el buen ejemplo un hombre bueno que un hombre de espíritu sobresaliente. Mis observaciones se refieren no sólo al ser humano que vive relativamente 
Este principio, además de una descripción, ofrece una explicación de los fenómenos de la masa y, especialmente, de sus características criminales instintivas tal como las consideraba Sighele. El instinto se usa aquí como un concepto psicológico más que biológico, e incluye todas aquellas acciones de la voluntad conducidas por ideas vagas.

Las únicas propiedades individuales que fermentan en la masa son aquellas que dejan salir a la superficie las propiedades comunes a todos los individuos ${ }^{8}$. Pero precisamente porque la masa es una aglomeración de seres humanos con características heterogéneas, el "alma de la masa» se compone con las propiedades más abyectas y brutales de los individuos, y la masa se abandona a la indómita pasión de una crueldad salvaje?

Aunque en esa primera obra Sighele se limita a estudiar la masa criminal, presenta ciertas observaciones generales que también pueden servir legítima-

disperso en la sociedad, sino también a las agrupaciones de muchas personas que se producen repentinamente. Me refiero a estados críticos de las agrupaciones humanas como los disturbios, las multitudes populares, las sectas, no a la convivencia social cotidiana. El principio examinado puede aplicarse siempre a esas asociaciones críticas. Esto es evidente y no requiere prueba. Si se observa cualquiera de estas agrupaciones de personas, encontramos que un grito, un gesto, una simple palabra, pueden elevar un sentimiento o una pasión, mientras que no hay, en cambio, ningún acontecimiento que pueda elevar el nivel espiritual o transmitir la chispa del genio a un millar de cerebros. Por consiguiente, las capacidades intelectuales no pueden sumarse, pues no pueden comunicarse por sugestión, y esto es así porque no poseen ningún medio material de transmisión.» Compárese con SimMEL, Soziale Differenzierung, p. 75.

${ }^{8}$ Sighele, Psychologie der Massenverbrechen, p. 18. "Se podría decir que todos los hombres normales poseen ciertas cualidades que les proporcionan la misma significación común -la llamaremos $\mathrm{x}$-; una significación a la que los hombres de mayor rango podrían añadir algo más, distinto para cada individuo, que llamaremos b, c, d, etc. Como resultado, en una reunión de 20 personas - incluso aunque fueran genios de primer orden - se llegaría a $20 \mathrm{x}$, pero sólo a un b, c, d, etc., y necesariamente los 20 x serían superiores a los b, c, etc., individuales; es decir, que lo humano-común que está repartido entre todos sofocaría la personalidad individual, y la gorra del trabajador cubriría el sombrero del doctor y del filósofo... En las agrupaciones de las que hemos hablado hasta ahora (jurados, colegios profesionales, corporaciones), al menos gobierna una determinada selección crítica de los individuos que las componen. Pero si ahora volvemos a aquellas otras colectividades reunidas por pura casualidad, como por ejemplo los asistentes a un mitin popular, los espectadores en el teatro, la gente que se congrega en las calles y en las plazas, vemos, entonces, que el proceso al que atendemos se manifiesta de nuevo con mayor claridad. Estos conglomerados de personas no manifiestan — cualquiera lo sabe, y no necesito adentrarme más en ello- la psicología de los individuos singulares que los componen.»

9 Ibid., p. 130. «En la confusión de hombres y de voces, donde nadie manda ni obedece, las emociones salvajes llegan a estar tan libres como las nobles y, por desgracia, los héroes, que no faltan, se encuentran inermes frente al ímpetu de los asesinos. Los asesinos son los que actúan; la mayoría, compuesta de átomos inconsistentes, se encuentra sin comprensión y sin ser capaz de rebelarse.»

Ibid., p. 206. «Desde luego hay algo desconsolador en las conclusiones a las que he llegado con Tarde. Las colectividades, llámense jurados o comités, llegan a peores resultados, moral y espiritualmente, que los que hubieran producido cada uno de sus miembros individuales. Por tanto, cuando una persona actúa junto a otras, eso significa un bajón de su nivel personal. Tenemos que acomodarnos a este resultado y, por tanto, a una fórmula pesimista.» Compárese con Tarde, Essais et mélanges sociologiques, pp. 21 y ss. 
mente para explicar otros tipos de grupos sociales. De hecho, en un estudio posterior (La delinquenza settaria), Sighele intentó aplicar los principios que derivaban de su primera obra a un material algo diferente. Presenta allí una nueva concepción de la masa. Tal concepto es, en este caso, más abarcante que el presentado en la obra anterior, donde Sighele se había limitado al fenómeno más llamativo del disturbio popular. Se trata ahora ya de la masa como concepto genérico que subsume toda una serie de especies secundarias como la secta, la clase social, la casta, etc.

La masa es, entonces, tanto la forma originaria como la general del grupo humano. Todas las formas del grupo derivan históricamente de la masa y, al considerarlas genéticamente, componen una línea ininterrumpida de desarrollo que arranca de esa forma nuclear hasta llegar al estado ${ }^{10}$.

Pero eso no es todo. Junto a este concepto general de la masa, reaparece el concepto en su sentido más estricto: el de masa criminal, disturbio popular, chusma.

En ese sentido más estricto, la masa no se diferencia de la secta. Ambas se contemplan como tipos especiales del concepto genérico de masa. La diferencia entre ellas reside en que la secta es una "forma crónica» de masa. Cuando el estado de ánimo colectivo, que controla sólo transitoriamente a los individuos de una masa, persiste durante más tiempo, nos encontramos con una secta. Lo que ocurre en este caso es que los individuos permanecen continuamente sometidos a la presión del oscuro ímpetu del impulso común ${ }^{11}$.

Sólo la transitoriedad distingue, por tanto, la masa de la secta. La masa es efímera y, por eso, con frecuencia, se prefiere hablar de movimientos de masas.

Esta tendencia a formar dos conceptos de masa, uno genérico y otro específico, tiene un interés lógico, porque muestra claramente cómo se hizo sentir

${ }^{10}$ Sighele, Psychologie des sectes, p. 41. «Un grito, un fuego, una bomba que explota en la calle o en el parque de atracciones, un descarrilamiento de un tren; en un momento la gente asociable se convierte en asociada para un fin común. He ahí, que una simple proximidad física da nacimiento a una reunión psicológica. Así se crea la masa que puede progresar a través de una serie infinita de grados pasando por la empresa hasta llegar al estado. "Hoy una masa y un estado tendrían que aparecer como dos agregados esencialmente distintos — de hecho lo son-, pero el segundo, bien mirado, sólo es un admirable desarrollo del primero. El estado moderno ciertamente no es más que la masa salvaje y primitiva transformada por siglos de historia en sociedad; un agregado de seres humanos unidos por una meta permanente, consciente y general, mientras que la masa sólo la tiene efímera, inconsciente y particular. El estado es una reunión de individuos cuya ley suprema y necesaria es la división y organización del trabajo, mientras que la masa es un ser inorgánico donde ninguno tiene un lugar determinado.»

${ }^{11}$ Sighele, Psychologie des sectes, p. 46. "La secta es una masa selectiva y permanente. La masa es una secta transitoria que no ha elegido a sus miembros. La secta es la forma crónica de la masa; la masa es la forma agudizada de la secta... La secta es, entonces, la primera cristalización de cualquier doctrina. Desde el estado amorfo y confuso en el que se manifiesta la masa, cualquier idea debe concretarse en la forma bien definida de la secta, a menos que más adelante se transforme en un partido, una escuela, o una iglesia científica, política o religiosa... Es el primer estadio en el que el grupo humano, dejando el estado indiferenciado de la masa desconocida, variada y anónima, se eleva a una especificación y a una integración que, enseguida, podrá conducir al grupo humano más alto y más perfecto: el estado.» 
la necesidad de una determinación conceptual más exacta, ante la fuerza de los hechos. En la inclinación de Sighele por llevar la definición de masa más allá de los límites establecidos en su primera obra podemos reconocer la influencia de Le Bon, que fue el primero que formuló la noción genérica de masa en su obra La Foule (die Masse) ${ }^{12}$.

En el trabajo de Gustave Le Bon encontramos un tratamiento del problema de la masa más sistemático e imparcial. Su enfoque estaba, ante todo, libre de los prejuicios, heredados de la escuela positivista del derecho penal, que pesaban sobre Sighele. No obstante, la definición de masa de Le Bon es esencialmente la de Sighele. Para ambos, el punto de partida es que la masa no puede considerarse como un simple agregado, sino que es más bien una entidad colectiva cuya unidad se basa en un tipo especial de dependencia recíproca entre los individuos que la componen. Con esta determinación del concepto, Le Bon rechaza el significado que suele darse habitualmente al término «masa». Al subrayar el aspecto psicológico, esto es la interacción entre los elementos individuales, asigna un significado puramente teorético a la palabra «masa» $(\text { foule })^{13}$.

Desde su perspectiva, Le Bon advierte ciertas condiciones bajo las que un agregado de personas adquiere características que son nuevas y distintas de las de un ser humano aislado. Bajo tales condiciones la totalidad se convierte en una entidad, como la denomina Le Bon, una masa psicológica (foule psychologique).

En el sentido usado aquí, masa difiere del significado usual de la palabra, en el que se ignora el aspecto espacial. Una muchedumbre de individuos reunidos en una plaza constituye una masa, en el sentido de Le Bon, sólo cuando posee un determinado carácter psicológico ${ }^{14}$.

La existencia de una masa es completamente independiente de la presencia simultánea de muchos individuos en un mismo lugar. De hecho, cuando por casualidad miles de individuos se encuentran en una plaza pública, en modo

${ }_{12}$ Ibid., p. 43. «Y ante todo puede observarse que el nombre de masa dado a cualquier grupo humano resulta impropio. Y desde el punto de vista gramatical, esta opinión me parece indiscutible. Con mayor precisión Tarde distinguía las asociaciones y las corporaciones de masas» (Nota de los trad.: Park traduce por masa — die Masse- la expresión francesa la foule).

13 Gustave Le Bon, Psychologie des foules, pp. 11 y ss.

${ }_{14}$ Ibid., p. 12. "Mil individuos accidentalmente reunidos en una plaza pública sin ningún fin determinado no constituyen, de ningún modo, una muchedumbre para la psicológía... En ciertos momentos, media docena de hombres pueden constituir muchedumbre psicológica, mientras que centenares de ellos reunidos por la casualidad pueden no constituirla. Por otra parte, un pueblo entero, sin que se produzca en él aglomeración visible, puede convertirse en muchedumbre bajo la acción de certas influencias» (Cfr. versión castellana, Psicología de las multitudes, Buenos Aires: EMCA, 1945, pp. 38 y 39). 
alguno constituyen una masa por su simple aspecto. Por otra parte, todo un pueblo puede ser, en determinadas circunstancias, una masa en el sentido psicológico del término, sin que dé visibles muestras de serlo. Son, por tanto, las condiciones psicológicas y no las relaciones espaciales de los individuos las que constituyen el momento determinante del concepto "masa» ${ }^{15}$.

¿Cuáles son, entonces, esos estados psicológicos de los individuos que podemos tomar como los rasgos característicos de un grupo sociológico? Le Bon sostiene que son dos:

1. La desaparición de todo contenido de conciencia individual y particular de los componentes de ese grupo; es decir que el individuo se sumerja en la masa, o lo que es lo mismo: la comparecencia de lo instintivo y de lo común, que defienden la vida de la especie.

2. El movimiento de los sentimientos y los pensamientos de todos en la misma dirección.

Le Bon ha sintetizado estos dos atributos en un concepto general, que designa con la expresión "alma colectiva». Una muchedumbre sólo puede ser denominada masa en sentido sociológico cuando los contenidos de conciencia de todos los componentes individuales del grupo están tan fundidos que el producto que se desarrolla a partir de ahí se debe considerar como una nueva entidad: como una conciencia colectiva (Gesamtbewusstsein). Entonces la muchedumbre se ha convertido en una masa, sociológicamente hablando ${ }^{16}$.

Lo que en la situación previa existía como una aglomeración heterogénea se transforma en una entidad homogénea.

Le Bon usó el concepto de "alma colectiva» de modos diversos según el contexto. No sólo habla de un alma colectiva y de la masa, sino también de un alma del pueblo. Al margen de cuánta homogeneidad o diferencia haya en el significado de estos términos en sus obras, es claro que la palabra incluye las dos características mencionadas antes y no tiene ningún sentido adicional ${ }^{17}$.

En Psicología de las multitudes se dice: «En ciertas circunstancias dadas, y solamente en estas circunstancias, una aglomeración de hombres posee caracteres nuevos muy diferentes de los individuos que componen esta aglomeración. La personalidad consciente se desvanece, los sentimientos y las ideas de todas

${ }^{15}$ Le Bon, Psychologie des foules, pp. 12-13; Sighele, Psychologie des sectes, p. 40; TARde, L'Opinion et la foule, p. 167. Compárese con LAZARUS Y STEINTHAL, Zeitschrift für Völkerpsychologie, I:11.

${ }^{16}$ LE Bon, Psychologie des foules, p. 20. «Desvanecimiento de la personalidad consciente, predominio de la personalidad inconsciente, orientación por vía de sugestión y contagio de los sentimientos y de las ideas en un mismo sentido, tendencia a transformar inmediatamente en actos las ideas sugeridas; tales son, pues, los principales caracteres del individuo en muchedumbre.» (Cfr. versión castellana, Psicología de las multitudes, Buenos Aires: EMCA, 1945, p. 49). Véase también Sighele, Psychologie des sectes, pp. 80, 85, 139.

${ }^{17} \mathrm{LE}$ BON, Les lois psychologiques de l'evolution des peuples, p. 11; Psychologie du socialisme, pp. 61, 62, 71, y Psychologie des foules, pp. 68, 72, 132. 
las unidades son orientados en una misma dirección. Se forma un alma colectiva, transitoria sin duda, pero que presenta caracteres muy puros» ${ }^{18}$.

La fusión de todo aquello que es individual y particular explica para Le Bon el conocido hecho de que la masa nunca es capaz de ejecutar nada que requiera un alto nivel de inteligencia ${ }^{19}$. La masa sólo tiene a su disposición aquellos atributos mediocres que cualquiera de sus miembros posee en grado similar ${ }^{20}$.

El representante más reciente de la psicología colectiva es Pasquale Rossi, quien ha escrito una serie de trabajos donde desarrolla la doctrina de Le Bon y Sighele en una dirección específica: en ellos la masa aparece ante todo como forma típica de la sociedad.

Para Rossi los tipos de masa forman una serie evolutiva en ascenso de formas de asociación que comienza con la forma inferior, más indiferenciada e inestable — las llamadas masas en el lenguaje coloquial_- y que culmina con la forma superior, más diferenciada y estable, es decir, con el estado ${ }^{21}$. Entre estos extremos se encuentran todos los grupos mencionados anteriormente como la secta, la clase, etc. El principio de clasificación es el de la diferenciación social progresiva, conjuntamente tomada con una creciente estabilidad que, en la misma medida, se reproduce también etapa por etapa. De tal suerte que se considera a la masa, tomada en sentido restringido, como lo más indiferenciado y efímero, en contraposición con el estado, que aparece como la forma de asociación más diferenciada y estable ${ }^{22}$. Este principio es precisamen-

${ }_{17} \mathrm{LE}$ BON, Les lois psychologiques de l'evolution des peuples, p. 11; Psychologie du socialisme, pp. 61, 62, 71, y Psychologie des foules, pp. 68, 72, 132.

${ }_{18}$ N. del T.: p. 45 de LE BON, Psicología de las multitudes, Buenos Aires, Editorial EMCA, 1945.

19 LE BON, Psychologie des foules, p. 17. «Precisamente esta comunidad de cualidades ordinarias es la que nos explica por qué las multitudes no sabrán nunca realizar actos que exijan una inteligencia elevada. Las decisiones de interés general tomadas por una asamblea de hombres distinguidos pero dedicados a especialidades diferentes no son sensiblemente distintas de las decisiones que tomaría una reunión de imbéciles. En efecto, todos ellos sólo pueden aportar a la misma aquellas cualidades mediocres que todo el mundo posee. En las muchedumbres lo que se acumula no es el talento, sino la estupidez.» (N. de los trad.: p. 45 de LE BON, Psicología de las multitudes, Buenos Aires, Editorial EMCA, 1945).

${ }^{20} \mathrm{La}$ incapacidad espiritual del grupo ha llamado ya la atención de otros autores. Cfr. TARde, L'opinion et la foule, p. 180; Sighele, Psychologie des sectes, p. 190; Sighele, Psychologie des Auflaufs und der Massenverbrechen, p. 26, y Lombroso, Die Anarchisten, p. 19.

21 Pasquale Rossi, L'Animo della folla, p. 4. "La masa puede definirse como una formación inestable e indiferenciada que evoluciona dentro de la esfera de un agregado estable y diferenciado (la ciudad, el pueblo, la aldea)... De esta forma primitiva de la masa, esencialmente inestable e indiferenciada, se pasa a otras formas más estables y diferenciadas. La evolución que es válida para los organismos sociales también incluye aquí una diferenciación y una integración crecientes.»

${ }_{22}$ Ibid., p. 12. «La forma última y más diferenciada de una masa es el estado, una forma estable que actualmente es un poder de mediación entre las diferentes clases o entre las diversas divisiones de una clase. Ahora es el órgano político de una sola clase.... Pero, la masa, la casta, la clase, el estado, la secta son realmente formas de evolución, eslabones en una cadena en la que el primero es la masa y el último es el estado.» 
te la ley general de la evolución de Herbert $\operatorname{Spencer}^{23}$, sólo que su aplicación es nueva, pues, en rigor, ya no es una ley de la evolución, sino un principio de clasificación. Sin embargo, hay que recordar que tal clasificación sigue siendo psicológica. En Rossi la diferencia entre la psicología colectiva y la sociología consiste en que la primera se ocupa del alma colectiva mientras que la sociología se ocupa de la complexión, del cuerpo, de la sociedad humana.

En las obras de Rossi el estudio de la psicología de la masa parece desbordar sus propios límites. De todos los escritores de esa escuela es él quien ha logrado la expresión más diestra y cabal de la doctrina. Fuera de esta escuela el problema de la masa sólo se trata ocasionalmente, y las descripciones concuerdan en lo esencial con las de Le Bon ${ }^{24}$.

Lo que distingue a los psicólogos de la masa es su énfasis en una unidad tomada como característica esencial del grupo social. En cambio, hay que considerar la masa como entidad colectiva, distinta de sus miembros, como un nuevo individuo espiritual.

Una vez que la masa se considera como una entidad nueva, como una realidad colectiva, podemos hablar de sus características. Los propios individuos que componen una masa muestran rasgos diferentes si actúan aislados o si están fundidos en una masa. Le Bon denominó "propiedades de la masa» a esas propiedades características de los individuos cuando están fundidos en una masa.

Estas propiedades, según Le Bon, son las siguientes:

1. Una sensibilidad emocional, una impetuosidad y una tendencia al capricho elevadas. El individuo aislado puede estar sometido a las mismas influencias que el que se encuentra en una masa, pero su intelecto le hace notar las consecuencias de su acción, y puede así contrarrestar los impulsos peligrosos. "El individuo», afirma Le Bon, "puede imponer una dirección determinada a sus reflexiones, mientras que la masa es incapaz de hacerlo» ${ }^{25}$.

Como a las masas pueden afectarles tipos muy diferentes de estímulos, y reaccionan indefectiblemente ante ellos, resultan ser muy volubles. Esto explica por qué la crueldad sedienta de sangre de una masa puede transformarse, en un instante, en magnanimidad o heroísmo sin límites.

${ }^{23}$ Confróntese Gaupp, Herbert Spencer, p. 93.

${ }^{24}$ Sighele, Psychologie des Sectes, pp. 41, 196, 192. TARde, L'opinion et la foule, p. 167; BALDWIN, Social and ethical Interpretations in mental Development, pp. 245 y ss.; SiDIS, Psychologie of Suggestion, p. 304; Sighele, Psychologie des Auflaufs und der Massenverbrechen, p. 28. Confróntese Dr. M. CAMPEAnO, Essais de psychologie militaire, individuelle et collective, Pasquale Rossi, La Psicologia collettiva morbosa.

${ }^{25}$ LE BON, Psychologie des foules, p. 25. 


\section{Una sugestionabilidad y una credulidad acrecentadas.}

La masa se entrega a todas las sugestiones. No tiene sentido crítico, y como resultado manifiesta una credulidad extrema. Los mitos y leyendas más increíbles pueden surgir y difundirse en una masa ${ }^{26}$.

3. La exageración y la unilateralidad de las opiniones

La masa, "como las mujeres», pasa enseguida de un extremo a otro. La simple mención de una sospecha da lugar a su inmediata consideración como un hecho incuestionable. En la masa la persona simple e ignorante pierde su sentimiento de insignificancia, que se sustituye por la idea de un poder ilimitado. Eso lleva a otra propiedad de la masa:

4. La intolerancia y el despotismo ${ }^{27}$.

La masa es tan despótica como intolerante. El individuo puede atender argumentos en pro y en contra; la masa, por el contrario, nunca puede hacerlo. En las reuniones públicas se recibe ruidosamente la más leve contradicción de un orador. Si el orador insiste en mantener sus puntos de vista, fuertes gritos piden que lo expulsen. La última de las «propiedades de la masa» que reclama la atención, es:

5. Su impersonalidad ${ }^{28}$. La masa es más capaz de sacrificio y de actos altruistas que el individuo. Mientras que en la masa el interés personal rara vez funciona como una fuerza motivadora poderosa, cuando los individuos actúan solos ocurre casi exclusivamente lo contrario ${ }^{29}$.

Resulta fácil explicar las llamadas "propiedades de la masa», la sensibilidad elevada, la credulidad, la intolerancia, etc. Son tan sólo expresiones diferentes de un estado emocional que es generado por la influencia recíproca de las emociones individuales y que afecta a todos los miembros de la masa de la misma manera.

El resultado de todo el proceso a través del cual se da vida a la masa, es la producción de una excitada disposición motora, es decir, un estado de sugestionabilidad que no pocas veces se da en un grado que se ha comparado con el de la hipnosis ${ }^{30}$.

Este estado de sugestionabilidad puede ser considerado como un estado de la masa porque afecta del mismo modo a todos los miembros del grupo y,

${ }^{26}$ LE BON, Psychologie des foules, p. 28.

${ }^{27}$ Ibid., pp. 38-39.

${ }_{28}$ Ibid., p. 41.

${ }^{29}$ Ibid., pp. 45-46.

${ }^{30}$ SIDIS, The Psychology of Suggestion, p. 327. «La sugestionabilidad social es hipnotismo individual a gran escala. Las leyes de la hipnosis funcionan a gran escala en la sociedad. La sugestión hipnótica es especialmente efectiva si concuerda con el carácter del sujeto. Lo mismo resulta cierto en el caso de la hipnotización social. Cada nación tiene su propia inclinación mental y las sugestiones que se producen en esa dirección son fatalmente efectivas. El judío es un buen ejemplo. Las emociones religiosas están en la base de su carácter y él es también muy sugestionable por las sugestiones religiosas.» 
sobre todo, porque depende de las influencias recíprocas que se producen entre los individuos. Por eso, se usa la expresión sugestión de masas ${ }^{31}$.

\section{V}

Si se intentara lograr una imagen completa de todo lo que se ha escrito sobre la masa, resultaría evidente que ciertos motivos científicos han influido en la formación de la noción de masa. Hay que examinar estos motivos para entender a fondo el concepto y su significación científica ${ }^{32}$.

Tal como se usó en primer lugar en la escuela de la psicología de masas, el término «masa» significaba lo mismo que disturbio popular, pero esto no es una definición científica. Cuantas veces aparece la palabra en su uso cotidiano, sus aplicaciones y matices son tan amplios y variados que imposibilitan una definición clara y precisa del concepto. El significado más específico de la palabra se refiere a una reunión de un cierto número de personas en algún lugar. Dicho así, una masa sería como un montón de piedras, nada más que un conjunto de individuos recíprocamente independientes que aparecieran ante la vista o al menos fueran percibidos mentalmente como una unidad real. Una unidad así, que en último término descansa simplemente en las relaciones espaciales entre sus partes, y no en sus interacciones recíprocas, no es una unidad real, y no puede constituir como tal el objeto de una ciencia explicativa. No puede, puesto que las partes de una unidad real están, precisamente, en una relación dinámica entre sí, siendo esa relación interactiva de carácter dinámico lo que constituye la «naturaleza» del conjunto ${ }^{33}$.

Es esa "naturaleza» o legalidad basada en las relaciones internas la que puede ser objeto de explicación científica, pues cada ciencia explicativa encuentra su materia de investigación en objetos compuestos de partes que están en relación dinámica entre sí. Por tanto, el procedimiento común de todas las explicaciones

${ }^{31}$ STOLL, Suggestion und Hypnotismus. «Sobre todo hay dos características del proceso de sugestión que son importantes en la psicología de los pueblos (Völkerpsychologie).

La primera es la facilidad con la que pueden suscitarse las ilusiones sugestivas en un gran número de personas completamente despiertas. La segunda es la enorme contagiosidad de ciertas sugestiones, es decir la posibilidad de producir una y la misma sugestión a toda una masa de personas; de aquí la suggestion collective de los franceses.»

32 RICKERT, Die Grenzen der naturwissenschaftlichen Begriffsbildung, cap. 1.

${ }_{33}$ KistiaKOWSKI, Gesellschaft und Einselwesen, pp. 114 y ss. «Todas estas entidades (los bosques, las montañas y las sociedades animales como los rebaños y los enjambres) existen como algo más que construcciones lógicas y no tienen un mero origen conceptual. Por el contrario, otros conceptos colectivos, que sólo son categorías artificiales de cosas o procesos similares, simplemente comprenden la coincidencia espacial y temporal de ciertos hechos. Estas entidades sólo pueden ser vistas como conceptos de agregados numéricos; la repetición de algunas de sus formas características constituye la única base para utilizarlas como entidades conceptuales.»

Ibid., p. 128. «En lo que concierne a la unidad del todo social, cabe decir que no consiste en las condiciones externas de su realización o en cualesquiera otros vínculos intermedios entre sus miembros particulares, sino en el proceso que tiene lugar en y entre los individuos o en la interacción psicosocial.» 
científicas implica dividir una cosa en sus partes para deducir, a partir de su interconexión, la naturaleza del conjunto - es decir la legalidad de su generación, de su disolución o de otro comportamiento-y someterlo a leyes ${ }^{34}$.

Resulta entonces claro que la psicología de la masa debe formar una noción nueva de su objeto para explicar el fenómeno de la masa, una noción que presente el todo como un ser determinado por las relaciones necesarias entre sus partes integrantes.

Aquí el enfoque de la psicología colectiva se separa de la visión ordinaria. Para una ciencia explicativa, la reunión en el espacio no constituye la característica esencial de la masa ${ }^{35}$. Podemos considerar como una masa a los individuos no porque estén juntos, sino porque se contagian recíprocamente mediante sus pensamientos y sentimientos.

Es un hecho de la experiencia común que, bajo la influencia de un estímulo colectivo, los hombres realizan a menudo acciones que nunca podrían hacer, y que ni siquiera se plantearían como individuos particulares. De ahí que los autores de la escuela de la psicología colectiva recurran frecuentemente e esta máxima: «Senatores boni viri; senatus autem mala bestia». Ciertamente, lo que ha captado en primer término la atención de la psicología colectiva es la conocida tendencia a la furia carente de sentido y al ciego espíritu destructivo que nacen de la pasión del disturbio popular, superando todas las pasiones individuales ${ }^{36}$.

También es cierto, y constituye igualmente un hecho de experiencia, que la masa es capaz de realizar actos heroicos que ninguno de sus miembros indivi-

${ }^{34}$ RICKERT, Die Grenzen der naturwissenschaftlichen Begriffsbildung, p. 212. «Si queremos usar la palabra (naturaleza) como término lógico en la doctrina científica habremos de decir que la naturaleza es la realidad considerada en su conexión legal.»

Ibid., p. 129: "Por consiguiente, aplicaremos la palabra "explicación" a un tipo particular de concepción; con ello intentamos decir que una explicación científico-natural sólo se da cuando se ha subsumido un fenómeno en un concepto; este concepto debe de haber alcanzado el tercer estadio. Lo que significa que no sólo es una definición o una compilación de características, sino que expresa una conexión necesaria, es decir una ley natural de incondicionada validez general. Cuando se logra esto tenemos una explicación que llamamos "causal", es decir sabemos cuándo se puede aplicar este concepto legal, porque algo es así, o tiene que comportarse así.»

35 Ibid., p. 67. «Sabemos que el presupuesto para la máxima efectividad del concepto científico natural es que esté libre de determinaciones espaciales y temporales para que pueda aplicarse a cualquier tipo de configuración de la realidad aun cuando puedan tener determinaciones espaciales y temporales.»

${ }^{36}$ SIDIS, The Psychology of Suggestion, p. 304. «En mi artículo "A Study of the Mob”, señalé que la turba tiene su propio sí mismo, que el sí mismo personal se suprime engullido por aquella hasta el punto de que, cuando regresa a la luz del día, frecuentemente está horrorizado por la obra, por el crimen, que la propia turba ha cometido; indiqué también que una vez que la propia turba se genera o, por decirlo mejor, cuando emerge a la superficie, posee un gran poder de atracción y tiene una gran capacidad de asimilación. Atrae a nuevos individuos, quiebra su vida personal y los asimila rápidamente; produce en ellos una disgregación de la conciencia y asimila los sí mismos subconscientes. La propia turba surge a partir de los si mismos subconscientes. El individuo asimilado no expresa otra cosa que la energía de la sugestión, la voluntad de la turba hechizada; entra libremente en el espíritu de la turba». 
duales tendría el valor de intentar aisladamente. Fue Le Bon quien primero subrayó esta propiedad. Puso, no obstante, tal énfasis en ese hecho, que podría parecer que sólo consideraba capaz de heroísmo a un individuo cuando actuara bajo la influencia de la excitación de la masa ${ }^{37}$.

Hay que concluir de todo ello que la influencia sugestiva ejercida por unas gentes sobre otras constituye la característica determinante de la masa; la epidemia social llega a ser así el fenómeno social típico para la psicología colectiva $^{38}$. Parece que los estados mentales o las disposiciones volitivas se combinan entre sí en una relación causal directa, y que su interacción conjunta suscita una excitación general que domina al grupo como un todo.

Los grandes ejemplos clásicos de los movimientos de masas son las últimas grandes migraciones de pueblos, las Cruzadas y la Revolución francesa. Sirven como ejemplos de los efectos temporales y espaciales de propagación de la epidemia social. Aquí el movimiento de masas aparece con un gran poder revolucionario que sacude y trastorna toda una civilización. Ejemplos de la influencia sugestiva que ejercen los hombres entre sí se dan en todos los ámbitos de la vida social. En este sentido, los fenómenos conocidos en diferentes lugares, en los siglos XIV y XV, como bailes de San Juan y de San Vito son sumamente interesantes. Por lo demás, ese tardío furor medieval por la danza no era un fenómeno nuevo, sino que era ya bien conocido en la Edad Media ${ }^{39}$. Semejanzas con la verbena medieval se encuentran en la exuberancia de las bacanales, festivales de danza de la antigüedad, y en el modo en que, a pesar de todas las fuertes resistencias, se extendieron como una epidemia por toda Grecia. Un libro reciente de Stoll demuestra que esta «sugestión de masas» no sólo comparece en casos aislados de la vida social, sino que ha jugado un rol importante por doquier tanto en la vida de los hombres de la naturaleza como en la de los de la cultura ${ }^{40}$.

La pretensión de la psicología colectiva de convertirse en una ciencia social explicativa se fundamenta, precisamente, en esa difusión general de la sugestión de masas.

${ }^{37}$ LE Bon, Psychologie des foules, p. 45. "Solamente las colectividades son capaces de grandes desintereses y de grandes abnegaciones." (Cfr. versión castellana, Psicología de las multitudes, Buenos Aires: EMCA, 1945, p. 82.)

${ }^{38}$ SIDIS, Psychology of Suggestion, pp. 310-311. «El hombre es un animal social, sin duda, pero es social porque es sugestionable. La obediencia ciega es una virtud social. Pero la obediencia ciega es la verdadera esencia de la sugestionabilidad: la constitución del disgregado sí mismo subconsciente. La sociedad, por su propia naturaleza, por su organización, tiende a convertir los tumultos en turbas, manías, modas y todo tipo de epidemias mentales.»

39 ROHDE, Psyche, Seelenkult und Unsterblichkeitsglaube der Griechen, p. 325.

40 STOLL, Suggestion und Hypnotismus in der Völkerpsychologie. Cf. HeCKer, Die Tanzwut, eine Volskrankheit im Mittelalter; Der scharwarze Tod im 14. Jahrhundert; y Kinderfahrt, eine historische pathologische Skizze; FÖRSTEMANN, Die Christliche Geisslergesellschaft; YANDELL, "Epidemic convulsions", Brain, vol. 4, 1881-82; REGNARD, Les maladies épidémiques de l'Esprit; FRIEDMANN, Ueber Wahnideen im Völkerleben, y v. BECHTEREW, Suggestion und ihre soziale Bedeutung. 
Pero, del hecho de que el contagio emocional sea un fenómeno tan extendido, surge una dificultad palpable: no resulta claro cómo hay que trazar las fronteras entre los grupos sociales. Si los fenómenos de masas coinciden con los de la sugestión social, entonces podría parecer que hay que considerar la masa como un simple estado de ánimo - que controla a cierto número de individuos- cuyos límites son tan difíciles de definir como los estados del tiempo atmosférico. En este caso apenas podría asignarse a la masa el atributo de la substancialidad. En lugar de eso, sería, entonces, obligado el considerar a la masa como una cualidad o un estado de alguna cosa.

Todos vivimos continuamente en una atmósfera de sugestión social de ese tipo dado que nuestros sentimientos y pensamientos están siempre influidos y definidos, hasta cierto grado, por los sentimientos y pensamientos de los otros. En todo encuentro se experimenta una influencia emocional y mental. Toda ocasión, ya se trate de una boda o de un funeral, tiene un peculiar ambiente que domina los ánimos de los asistentes. Dos individuos se sientan en una mesa y comienzan a hablar entre sí. Con independencia de su grado de distanciamiento o de coincidencia, comienza a desarrollarse inmediatamente entre ellos un ambiente compartido que afecta a ambos en el mismo grado. Seguidamente una tercera persona se sienta con ellos y en ese momento el ambiente cambia, se desarrolla uno nuevo. Este proceso de interacción y de ajuste espiritual está siempre activo, continua y automáticamente, dondequiera que haya varias personas juntas. Habitualmente no somos conscientes de la influencia de estas fuerzas sociales que nos rodean. Sólo se hacen conscientes cuando pasamos de un círculo social a otro o cuando la atmósfera espiritual experimenta una repentina perturbación.

Desde este punto de vista la masa aparecería como un simple movimiento de esa atmósfera, como una perturbación del equilibrio social.

No hay duda de que se presenta una dificultad real cuando se toma en serio el concepto de «masa». La misma indeterminación de tal concepto se manifiesta también al encarar la difusa descripción de los tipos de masa que han utilizado los diversos autores.

Aunque emplea la masa como un concepto general y trata de subsumir en él los tipos más diversos de grupos sociales, Le Bon distingue claramente entre masa y pueblo ${ }^{41}$.

${ }^{41}$ LE Bon, Psychologie des foules, p. 143. Le Bon ha clasificado las masas del modo que sigue: Masas heterogéneas:

1. Anónimas (masas reunidas en la calle, etc.)

2. No anónimas (jurados, asambleas parlamentarias, etc.).

Masas homogéneas:

1. Sectas (políticas, religiosas, etc.).

2. Castas (militar, sacerdotal, obrera, etc.).

3. Clases (burguesa, clases campesinas, etc.). 
Tarde toma el concepto de masa en un sentido mucho más restringido que Le Bon y otros autores. Por ejemplo, distingue entre masa y público, y para él la secta no es un tipo particular de masa ${ }^{42}$.

Sighele se sitúa entre Tarde y Le Bon, puesto que, primero, define la masa en un sentido más estricto y, posteriormente, en un sentido más amplio. Finalmente, Rossi se distingue de los anteriores al sostener que la masa y el grupo social coinciden esencialmente.

Pero, a pesar de estas diferencias, todos los autores de esta escuela asumen esta hipótesis: que la característica determinante de la masa no es la yuxtaposición espacial, sino la presencia de interacción espiritual.

No obstante, la interacción sola no constituye el ser de la masa. Siempre que la interacción sugestiva de los hombres alcanza cierto grado de intensidad, los seres humanos son tan fuertemente atrapados por corrientes emocionales y de pensamiento que resultan arrastrados como por una riada y conducidos hacia una meta inconsciente. De este modo se ve cómo ciertos individuos se sustraen de la sociedad circundante y se encadenan a un nuevo centro y foco de sentimientos y pensamientos. En última instancia es a una corriente espiritual de ese tipo, junto a los individuos arrastrados por ella, a lo que la psicología colectiva ha dado el nombre de «masa $»^{43}$.

Lo relevante en esta interpretación de la masa no consiste sólo en el hecho de que en ella se modifiquen, promuevan e inhiban recíprocamente los sentimientos y las disposiciones volitivas de cierto número de personas; sino en el de que todo el proceso se oriente hacia una y la misma meta, y que la unidad que de ese modo se produce sea teleológica. Esto es lo que quiere indicarse cuando la psicología colectiva atribuye un alma a la masa. Es ahí donde hallamos la sustancialidad del grupo.

Con respecto a la relación de masa con el pueblo, confr. LE BON, Psychologie des foules, pp. 67 y ss., y Les Lois psychologiques de l'Evolution des peuples.

${ }_{22}$ TARDE, L'opinion et la foule, pp. 1 y ss. y p. 202. "Una masa, incluso cuando se componga de una mayoría de gente buena, puede ser arrastrada fácilmente a ciertos tipos de crímenes pasionales, a accesos de alienación homicida momentánea; mientras que una secta, animada por un sentimiento fuerte y tenaz, sólo comete crímenes pensados y calculados que se conforman siempre con su carácter colectivo y que están fuertemente marcados por el sello de su raza.»

43 TARDE, L'opinion et la foule, p. 175. «Contempladas en un mismo vistazo, todas las reuniones tumultuosas que proceden de una agitación inicial, y que están íntimamente relacionadas entre sí, fenómeno habitual de las crisis revolucionarias, pueden considerarse como una y la misma masa. Pertenecen a la categoría de masas complejas, que se encadenan por series de ondas.» 


\section{CAPITULO II \\ EL PROCESO SOCIOLOGICO}

Si consideramos la sociología como prototipo de ciencia social descriptiva y explicativa - eludiendo así la costumbre de tratarla como filosofía de la historia ${ }^{1}$ - , se nos imponen ciertas dificultades específicas de carácter lógico que no se dan en otras ciencias de la naturaleza ${ }^{2}$. Esas dificultades consisten en que el objeto de la sociología, el grupo social, no es percibido por los sentidos como una unidad física.

El grupo social aparece ante la conciencia ingenua simplemente como un conjunto de individuos separados espacialmente cuya independencia recíproca se acepta, sin discusión, como algo patente. A partir de ahí puede explicarse claramente que aquello que las otras ciencias conciben como algo dado, a saber, la unidad y cohesión de su objeto, viene a resultar un problema para la sociología.

La actividad científica suele comenzar con la descripción y clasificación de objetos como los árboles, las personas, las piedras, etc., a los que la percepción ingenua atribuye una unicidad sustancial y una forma sólida e invariable. No obstante, cuando se examina más de cerca esta forma que a simple vista aparece sólida y sustancial, se cae en la cuenta de que está en permanente cambio; suele ocurrir, entonces, en dicha actividad, que se intenta salvar la sustancialidad de las cosas dividiendo el objeto en sus elementos, que a su vez vuelven a ser considerados sólidos e invariables. Su unicidad se transforma en un juicio universal en el que se determinan las relaciones cambiantes entre ellos. De este modo la sustancialidad del objeto se convierte en la ley que rige las relaciones recíprocas de sus elementos ${ }^{3}$.

La sociología, por el contrario, no puede proceder de este modo porque el grupo social no viene dado como unidad y, de entrada, es preciso convertirlo en tal unidad. Cabe hablar del grupo social como una unidad real, como una unidad que puede llegar a ser objeto de explicación científica, si se cae en la cuenta de que las relaciones sociales pueden interpretarse causalmente, y, además, de que dichas relaciones recíprocas pueden, eventualmente, expresarse en leyes ${ }^{4}$.

${ }^{1}$ Confróntese Paul Barth, Die Philosophie der Geschichte als Soziologie, Prólogo, p. 4. «Para mí la historia aparece como sociología concreta, del mismo modo que el drama es caracteriología concreta. Sin embargo, una teoría de la historia será necesariamente abstracta y se identificará con la sociología abstracta.» Véase también ibid., pp. 4 y ss.

${ }^{2}$ En este estudio partiremos del contraste metodológico entre historia y ciencia natural tal como lo propone WINDELBAND ("Geschichte und Naturwissenschaft», Strassburger Rektoratsrede, 1894), y también RICKERT (Die Grenzen der naturwissenschaftlichen Begriffsbildung). Cfr. también Simmel, Die Probleme der Geschichtsphilosophie; Münstenberg, Grundzüge der Psychologie, pp. 133 y ss.; KistiaKOWsKI, Gesellschaft und Einzelwesen, pp. 42 y ss.

3 Confróntese SIGWarT, Logik, vol. 2, parágrafos 76-79.

${ }^{4}$ KIsTIAKOWSKI, Gesellschaft und Einzelwesen, pp. 111 y ss. 
Si admitimos que la unidad del grupo consiste en su unidad de acción, de modo que el grupo puede ser considerado como unidad funcional — como lo hace por ejemplo la psicología colectiva_-, se plantea entonces, al respecto, nuevamente - aunque se haga de una forma distinta_ la vieja cuestión: ¡cuál es la base física del grupo? El problema de la sociología se muestra en este punto en su forma más enigmática. La dificultad reside en que los mismos individuos aparecen como miembros de grupos diferentes. A, B, C y D, por ejemplo, pueden ser miembros de la bolsa y pertenecer a la vez a los mismos círculos sociales. Resulta, entonces, que una misma base física parece estar compartida por dos configuraciones sociales completamente diferentes, cuyos intereses y tradiciones son totalmente distintos.

Al igual que los miembros no pueden servir de base física de un grupo, tampoco pueden servir para eso los instrumentos que usan. Las dificultades planteadas en una investigación de este tipo resultan más claras cuando se considera que los equipamientos - especialmente las herramientas, los utensilios y máquinas como el ferrocarril, el telégrafo y la imprenta, etc. - sólo pueden considerarse como una «extensión del sistema de respuesta sensomotora, como miembros separables del mecanismo psico-físico del individuo ${ }^{5}$ Precisamente porque estos equipamientos sociales pertenecen a todos los individuos y a todos los grupos, y pueden convertirse en objeto de reivindicación al ser demandados por unos y otros, no pueden servir, en modo alguno, para distinguir físicamente un grupo social de otro.

Mejor cabría esperar que se encontrara la base física del grupo en el cerebro y en la fisiología del sistema nervioso, pues se sabe que cuando se estimula cualquiera de los sistemas motores del cerebro todos los demás se inhiben más o menos. Por ello, hay que suponer que cuando un conjunto de individuos trabajan juntos se tiene que desarrollar en cada uno de ellos un sistema motor particular en conexión con los sistemas motores paralelos de todos los demás individuos del grupo. Esto daría lugar a un sistema motor común como el que se ve, por ejemplo, entre los jugadores de fútbol americano, en el que cada movimiento de un individuo provoca un movimiento correspondiente en todos los demás. En la medida en que este sistema motor común inhibe todos los otros sistemas motores posibles, se

Münsterberg, Grundzüge der Psychologie, p. 477. «La herramienta, en el sentido más amplio de la palabra que cabe imaginar, es una extensión del sistema de respuesta sensomotora, una extensión que está separada mecánicamente del organismo aunque pertenece a él biológicamente, como la concha pertenece a los crustáceos y a los caracoles. Es importante para el sociólogo que el hombre cree la herramienta para sus objetivos de acuerdo con sus planes. El biólogo ve en esa planificación y creación una actividad cerebral y, por consiguiente, una función corporal a través de la cual la misma herramienta se convierte en un producto corporal. Aunque fisiológicamente resulte que el material con el que se hizo la herramienta no sea una secreción corporal, sino que venga de una materia prima externa, biológicamente esto es de importancia secundaria. Por ello, biológicamente no hay diferencia entre una tela de araña y un nido de pájaro; en un caso, el material permanece fuera del cuerpo, y en el otro, ha pasado a través del cuerpo y se ha transformado mediante un proceso vegetativo.» 
podría pensar que la estructura total correspondiente fuera la base física del grupo $^{6}$.

Aunque teóricamente la base física del grupo pueda determinarse de este modo, en la práctica nadie intentaría llevar a cabo esa definición en detalle. Tal vez una investigación práctica de ese tipo, al mostrarnos finalmente que no se puede determinar por ese camino la unidad del grupo social, nos obligaría a describirlo y explicarlo mediante conceptos fisiológicos. A partir de ahí se podría explicar el hecho de que, cuando la sociología deja de describir despreocupadamente las formas del vínculo en las que se expresa la vida social y trata de explicar esas formas y la propia vida, se convierte necesariamente en psicología social? .

Ese mismo problema surge al preguntar cuáles son los elementos de los que se ocupa la sociología. Hemos subrayado ya que el proceso común a todas las ciencias explicativas consiste en dividir un objeto en sus partes de tal modo que el todo pueda explicarse a partir de las conexiones entre éstas; lo que significa someter a leyes el fenómeno de su origen, el de su desaparición y el de cualquier circunstancia de su proceder. Toda ciencia explicativa convierte sólo una parte de la realidad empírica en objeto de su investigación, o, al menos, considera esa realidad empírica desde un punto de vista particular. Y, dentro de su área de investigación, cada ciencia intenta descomponer las cosas en aquellos elementos que considera como las unidades más pequeñas que no admiten examen ulterior.

Cabe así intentar una distinción lógica de las diversas ciencias naturales que se apoye en la variedad de los elementos con que operan. La explicación del objeto se produce cuando se interpreta su cambio como una interacción de elementos que se cumple de acuerdo con una regla. De este modo, las distintas ciencias se diferencian entre sí según: (1) sus elementos distintivos y (2) el tipo de interacción que se produce entre ellos ${ }^{8}$. Por ejemplo, en física el elemento es el átomo y la forma general de la interacción entre los átomos se expresa en la ley de la gravedad. En cambio, los elementos de la química son más concretos que los de la física, es decir, que manifiestan comparativamente más cualida-

${ }^{6}$ Bosanquet, The Philosophical Theory of the State, pp. 173 y ss.: "Cada mente individual, en la medida en que participa en las agrupaciones e instituciones sociales, es una estructura de sistemas aperceptivos que responden, respectivamente, a los diferentes roles en los que interviene en cada agrupación.»

Ibid., p. 175. «El todo social, considerado desde un punto de vista adecuado sería un todo consistente en las disposiciones psíquicas y sus actividades, que se responden, unas a otras, de modos determinados.»

7 SIMmel, «Das Probleme der Soziologie», Jahrbuch für Gesetzgebung, XVII, 4, p. 1301; MÜnSterberg, Grundzüge der Psychologie, p. 133.

${ }^{8}$ RiCKERT, Die Grenzen der naturwissenschaftlichen Begriffsbildung, p. 125. «La ciencia de la naturaleza no sólo yuxtapone las características para determinar los contenidos del concepto, sino que reúne un conjunto de elementos homogéneos y prepara con ellos un tipo de conceptuación que permita, finalmente, llegar a desarrollar conceptos con juicios generales o leyes naturales incondicionados.» 
des: son por sí mismos más determinados, y en sus relaciones recíprocas muestran una multiplicidad mayor, aunque sigan siendo plenamente determinables por la ciencia. La descripción y la explicación, tanto de los objetos químicos como de los físicos, consiste en el análisis de sus elementos y en la comprobación de la conexión que existe entre ellos, es decir, consiste en ambos casos en la transformación de una noción cosiforme en otra relacional. Ocurre, no obstante, que la química no lleva tan lejos el proceso como la física. Eso es lo que se quiere decir cuando se explica que el objeto de la química es más concreto que el de la física. Si atendemos ahora a la biología encontramos un elemento todavía más concreto y más determinado desde dentro. Ese elemento, la célula, posee, por ejemplo, características que le capacitan (1) para reproducirse y (2) para adaptarse al entorno. Se busca la explicación del organismo por medio de la interacción de las células, de su adaptación recíproca, de la división del trabajo, etc. ${ }^{9}$.

Es claro que, si fuera posible llevar a cabo esa división lógica, las ciencias formarían una serie ascendente donde cada paso hacia un sistema superior de relaciones encontraría siempre un elemento más concreto ${ }^{10}$. Esto no significa, sin embargo, que el objeto regido por las leyes de cualquier ciencia determinada no esté afectado por las leyes de todas las ciencias de orden inferior y más abstractas. Más bien sucede que los sistemas inferiores son prerrequisitos para la existencia de los superiores. La unidad básica nueva, más concreta, permite abstraer todas aquellas relaciones que son precisamente las que interesan a las ciencias más abstractas. Por tanto, aunque la célula puede explicarse física y químicamente, la biología no la explica así, sino que la trata como la unidad básica cuya esencia no puede reducirse más. Por el contrario, la química fisio-

9 RiCKERT, Die Grenzen der naturwissenschaftlichen Begriffsbildung, p. 282. "Por otro lado, sin embargo, la biología revela también un aspecto que es científico-natural en el sentido en que nosotros lo entendemos. Incluso cuando abandonamos el método descriptivo científico-natural no quedamos limitados a presentar la historia del organismo, sino que intentamos encontrar las leyes por las que se rige su vida o, por lo menos, tratamos de formar conceptos que puedan ser válidos dondequiera que esté. Tienen que ser abstraídos, si no del carácter histórico de los diversos tipos, al menos de los vivientes en general. La tendencia científica puede proceder, por ejemplo, refiriendo la plétora de formas que cambian continuamente a procesos, que, como procesos orgánicos, tienen ciertamente que seguir siendo siempre, desde el punto de vista de una teoría general del mundo corpóreo, históricamente relativos; pero que, comparados con las formas continuamente cambiantes de los organismos individuales, tienen que ser considerados como algo duradero y no cambiante. Se trata, entonces, exactamente de lo mismo que se hace en la física o en la química. La biología estudia la naturaleza dentro de lo histórico para convertirse en una ciencia de la naturaleza en el sentido en que lo son las demás ciencias.»

${ }^{10} \mathrm{Al}$ calificar a las diversas ciencias como supra o subordinadas no se pretende limitar la autonomía de las mismas. Y aún menos cabe considerar dicho orden como una relación de valor, ya que, desde un punto de vista lógico, la ciencia a la que llamamos aquí subordinada hay que considerarla realmente como superior porque entendemos que el interés lógico de la ciencia atomística es el más completo». Confróntese con Münsterberg, Grundzüge der Psychologie, p. 298. «Entender el objeto como un complejo de partes componentes es una transformación cuyo objetivo debe ser el de situar al objeto en una conexión de causas y efectos; es tanto más científica cuanto más comprensiva sea la conexión que el análisis depara.» 
lógica contemplaría la célula precisamente como el problema que hay que investigar.

Si avanzamos hasta la sociología cabe esperar que la unidad básica sea todavía más concreta que la de la biología. En este caso el propio individuo podría casi ser considerado como aquella unidad. Esta suposición existe de hecho en la economía política británica clásica, donde se equipara al individuo con el átomo físico como unidad uniforme e inmutable. La diferencia está en que, mientras el átomo está ligado por relaciones externas y es totalmente incapaz de autodeterminación, el individuo - tal como lo ve la economía política británica- actúa con absoluto arbitrio, guiado tan sólo por su impulso de autopreservación $^{11}$.

Frente a las hipótesis de la economía política, sabemos que los intereses de los hombres no residen siempre en sus propios cuerpos. El error del punto de vista contrario surge del enfoque psicológico, que establece siempre un paralelismo entre los procesos psíquicos y fisiológicos. De hecho, el «propio interés» que cae dentro del dominio de nuestro propio arbitrio abarca todo aquello de lo que nos sabemos responsables, ya sean nuestros hijos, nuestras propiedades, el resultado de nuestras acciones, nuestra riqueza o, incluso, el destino de nuestra alma inmortal. Más aún, estos «intereses propios» son tan diversos, y a menudo tan contradictorios, que en absoluto puede hablarse del yo (Selbst) empírico como de algo idéntico a sí mismo. Al contrario, el yo empírico está siempre cambiando y nunca es idéntico consigo mismo ${ }^{12}$. El interés de esto consiste en

11 W. Hasbach, Die allgemeinen philosophischen Grundlagen der von Quesnay und Adam Smith begründeten politischen Oekonomie, p. 141. «El método de Hobbes recibe su necesario complemento de la psicología de Descartes; ahora sí que llegaba a estar completo. Ricardo lo utilizó después de un modo tan hábil que su trabajo se convirtió en una mecánica de la vida económica e hizo posible un tratamiento totalmente matemático de nuestra ciencia. Tal era el objetivo al que conducía necesariamente esta dirección. Los matemáticos Descartes y Hobbes habían introducido en las ciencias del espíritu un método relacionado con las matemáticas; y, a través del genio de hombres como Cauard, Coumot, Gossen, Walras y Jevons, las matemáticas que habían estado latentes fueron liberadas.» Confróntese BONAR, Philosophy and Political Economy.

LANGE, Geschichte des Materialismus, 2:451. «Este error (el que los seguidores de Adam Smith confundieran las leyes del mercado con los fundamentos de la naturaleza humana) contribuyó incidentalmente a dar a la economía política un barniz de estricta cientificidad, que trajo consigo una considerable simplificación de todos los problemas del comercio. Esta simplificación consistió en pensar a los seres humanos como puramente egoístas, capaces de atender a la perfección sus intereses particulares sin sentirse estorbados por cualesquiera otros sentimientos.»

Bagenot, "The Postulates of Political Economy», Economic Studies, pp. 5 y ss. "Es cierto que personas más competentes han entendido que los economistas políticos ingleses no hablan de hombres reales, sino imaginarios; no de los hombres que vemos, sino de los hombres tal como nos conviene suponer que son. Pero, incluso ellos, no entienden con frecuencia que el mundo del que se ocupan nuestros economistas políticos es también un mundo muy limitado y peculiar. Imaginan a menudo que lo que leen es aplicable a todos los estados de la sociedad, y a todos del mismo modo, cuando esto sólo es cierto — y sólo está demostrado- respecto a estados de la sociedad donde el comercio se ha desarrollado ampliamente y con una forma de desarrollo como la de Inglaterra, o parecida a ella.»

12 James, Psychology, I:291 ss., y Bosanquet, Psychology of the Moral Self, p. 47. 
que el individuo no puede ser considerado como elemento. Ni desde el punto de vista propuesto, ni tampoco desde el sistema de relaciones que la sociología tiene que investigar, es el individuo permanentemente igual a sí mismo.

Cuando se compara la psicología colectiva y la economía política, se evidencia que, al menos, sus presupuestos son completamente contradictorios. Mientras que para la economía política los individuos egoístas representan los elementos con los que se forma la sociedad, la psicología colectiva no contempla al individuo como unidad espiritual. Su obrar no es mediado y conducido por una representación de su personalidad, sino dirigido directa e inmediatamente - de modo semejante a una conducta instintiva- por el objeto. Aunque admitamos que los respectivos supuestos de la psicología colectiva y la economía política británica clásica pueden justificarse dentro de sus ámbitos de investigación en atención a los diferentes intereses que representan, sigue abierta la posibilidad, e incluso la necesidad, de construir una ciencia desde una perspectiva que abarque a ambas ${ }^{13}$.

Los comienzos de tal ciencia se hallan en la llamada «teoría de la imitación" (imitation theory), localizada en las diversas formulaciones que ha adoptado en los escritos de sus defensores franceses y norteamericanos. En Francia, por ejemplo, Tarde ha emprendido una crítica de las nociones y de los supuestos psicológicos con que trabajaba la vieja economía política; su intención es desplazar la perspectiva de la economía basada en el individuo hacia la psicología social ${ }^{14}$. Baldwin, en los Estados Unidos, ha intentado explicar, además del grupo, el individuo espiritual, es decir, el individuo considerado como personalidad empírica, como productos de la interacción social ${ }^{15}$.

Esto indica claramente que ni Baldwin ni Tarde consideran al propio individuo el elemento de la sociología. Aunque Baldwin, igual que el Prof. Royce, ve al individuo como un resultado del proceso social. Los diversos autores no pueden ponerse en absoluto de acuerdo sobre qué es lo que hay que considerar elemento: Tarde pensaba en los deseos y creencias, y Baldwin, en cambio, sostenía que había que entender que esos elementos eran las ideas ${ }^{16}$. Pienso que el

13 Lange, Geschichte des Materialismus, II:455. "Sin duda, la abstracción del egoísmo es mucho más fuerte en la economía política que en cualquier otra ciencia anterior, donde tanto las influencias contradictorias de la desidia y la costumbre como las de la simpatía y el sentido de comunidad son de la máxima importancia. Con todo, esa abstracción puede aceptarse sin vacilar siempre que permanezca como tal abstracción en la conciencia. Porque, cuando se descubre cómo tendrían que comportarse esos átomos móviles de una hipotética sociedad que profesa el egoísmo si se rigiesen de acuerdo con los términos de tal suposición, entonces, no sólo se obtiene una ficción que no es en sí misma contradictoria, sino también se gana el conocimiento exacto de una faceta del ser humano y de un elemento que desempeñan un rol muy importante en la sociedad, de manera especial en el comercio.»

${ }^{14}$ Confróntese TARDE, Psychologie economique. (Nota trads.: la expresión inglesa procede del original.)

15 BALDWIN, Social and Ethical Interpretations, pp. 13 y ss.; ROYCE, "Observations on Anomalies of Self Conciousness", Psychological Review, vol. II, núm. 5.

${ }^{16}$ Respecto a la unidad psicológica básica, cfr. TARDE, Études de psychologie sociale, pp. 41 y ss.; Les lois de l'imitation, pp. 1 y ss.; La logique sociale, pp. 12 y ss., y L'opposition universelle, 
desacuerdo entre estos dos autores surge de cierta diferencia en sus puntos de vista de la que nos ocuparemos más adelante. A nuestros efectos, los hechos sociológicos elementales son las disposiciones volitivas (willattitudes) de los individuos que se influyen recíprocamente en un grupo. Esas disposiciones pueden expresarse en la conciencia como sentimientos (deseos y creencias) o como ideas.

Finalmente, debemos hacer notar, como se vuelve a ver en este caso, que la unidad sociológica no coincide con ninguna unidad física determinada. Los individuos físicos componen, junto con todos los dispositivos sociales con los que se influyen, un amplio mecanismo psico-físico; pero éste por sí solo no constituye unidad sociológica alguna, pues tal unidad consiste, más bien, en la unidad funcional que se realiza a través de ese mecanismo.

No hay nada nuevo en la opinión de que el hombre tiene un significado muy especial para sus semejantes (Mitmenschen), en comparación con el de los objetos del mundo exterior, y que está naturalmente dotado para reaccionar de modo diferente hacia los otros seres humanos que hacia los objetos. Más aún, esta idea es vieja. La mantuvieron los estoicos, y se introdujo en la filosofía moderna formando parte de la doctrina ético-jurídica del Renacimiento ${ }^{17}$.

Durante la Ilustración inglesa, este punto de vista reapareció en la teoría acerca de un "estado moral original» de los hombres, erigida en contraposición con la teoría de Hobbes, según la cual un hombre no tiene ante sus semejantes un valor especial que lo distinga del que le ofrecen otros objetos útiles en la naturaleza. Por eso, para Hobbes, como para Locke, el fundamento de toda la

p. 339: «La cantidad psicológica es la creencia o el deseo en la medida en que pasan o son capaces de pasar, en el mismo individuo, de un grupo de sensaciones e imágenes a otro sin por ello alterarse profundamente. La cantidad social es la creencia o el deseo en la medida que son comunicados o comunicables de un individuo a otros, sin cambiar de naturaleza. Cuando la creencia se acumula en un individuo se convierte en convicción; cuando se extiende e intensifica en las masas, toma el nombre de verdad.»

BALDWIN, Social and Ethical Interpretations, p. 505. «Solamente los pensamientos o el conocimiento se pueden imitar de ese modo fructífero que una teoría de la organización social progresiva exige. Alguien ha dicho que las creencias y deseos son imitables en esos términos, sin embargo, los psicólogos tienen claro que las creencias y deseos son funciones de los contenidos del conocimiento respecto a los cuales surgen. Un individuo no puede inducir creencia alguna en otro salvo cuando antes se induce el hecho que se cree, la verdad, la información creídas. El imitador debe captar primero el pensamiento para poder imitar después la creencia en el pensamiento. Lo mismo vale para el deseo. No puedo desear lo que deseas a menos que piense el objeto deseable como tú lo haces. Tanto la creencia como el deseo son, como hemos argumentado antes, funciones del contenido del pensamiento.»

17 Windelband, Die Geschichte der neueren Philosophie, I:269 ss.; Bonar, Philosophy and Political Economy, p. 72. 
conducta moral reside fuera de la naturaleza humana, concretamente, en la autoridad $^{18}$.

En estrecha conexión con esa doctrina que afirmaba la existencia de un impulso social natural que expresaba la naturaleza social del hombre se desarrolló gradualmente otra teoría propiciada por una psicología de los impulsos humanos más profunda y de mayor alcance. Esta nueva teoría consideraba que las acciones de los hombres, y concretamente las que llamamos morales, son suscitadas y determinadas, al menos en parte, por el efecto reflejo del sentimiento ajeno sobre nuestra vida interior.

Encontramos por primera vez esta doctrina clara y plenamente desarrollada en la obra de Hume con el nombre de "simpatía» (Sympathie); pero es posible reconocerla también, ocasionalmente, en las enseñanzas de autores anteriores. Ya Bacon, que había admitido a su manera la existencia de dos impulsos principales que movilizan la conducta humana —uno dirigido al bien propio y otro al bien común-, hizo alusión a la importancia de la «imitación simpatética» y trató de explicar este fenómeno como una "transmisión de los espíritus» (transmission of spirits) ${ }^{19}$.

La doctrina de la simpatía de Hume estaba implícita ya en la teoría del obispo Joseph Butler, en la que los sentimientos morales se consideran como «afectos de la reflexión». Butler "descubrió que los motivos para obedecer a las leyes morales, que él consideró como mandamientos divinos, están en parte en los efectos retroactivos de nuestra previsión del juicio que nuestras acciones van a encontrar en Dios y en los hombres» ${ }^{20}$.

Pero el propio Butler, aunque fue el primero que convirtió en principio explicativo la respuesta recíproca entre los espíritus de los hombres, se limitó a tomar ese principio como una regla práctica para explicar y fundamentar un mandamiento divino existente ya en la naturaleza humana.

En Hume, que negó la validez universal de los mandatos morales, esta doctrina de la simpatía recibe, por contra, la forma de un principio fundamental, y su ética desemboca en una sociología. La filosofía ética escocesa se sacude aquí sus arreos de ciencia normativa y se manifiesta simplemente como una ciencia descriptiva y explicativa ${ }^{21}$.

Según Hume, la simpatía es una resonancia de sentimientos ajenos derivada de la semejanza constitutiva entre los hombres. La simpatía se produce porque nos situamos en la posición de otros y reproducimos sus sentimientos. Hay aquí dos puntos significativos: (1) que esta reproducción de los senti-

18 Windelband, Die Geschichte der neueren Philosophie, I:154, 266, 276; Butler, Sermons on Human Nature, p. 93.

19 Jodl, Geschichte der Ethik, p. 198; BACON, De Aug. Scient., lib. IV, cap. 1, y Sylva Sylvarum, p. 112. Confróntese Dugald STEWART, vol. III, que cita este pasaje de Bacon. (Nota de los trads.: la expresión inglesa aparecía en el original.)

20 Windelband, Die Geschichte der neueren Philosophie, I:276; Butler, Sermons on Human Nature, pp. 42, 44.

${ }^{21}$ Windelband, Die Geschichte der neueren Philosophie, I:349. 
mientos ajenos resulta de cierta necesidad natural y (2) que los sentimientos transmitidos producen movimientos correspondientes en el receptor, de modo que éste obra a partir de los sentimientos transmitidos exactamente como si procedieran de su propia naturaleza ${ }^{22}$.

Más tarde, Adam Smith, amigo y discípulo de Hume, continuó y desarrolló todavía más su doctrina ética en la obra The Moral Sentiments, aunque sin cambios esenciales en los principios básicos. La ciencia social moderna recibió la doctrina de la simpatía (Sympathie) de Adam Smith por dos caminos separados. Dugald Stewart, uno de los seguidores de Smith, desarrolló el aspecto psicológico de la teoría y lo relacionó con los fenómenos de la imitación involuntaria y del hipnotismo. La aplicación sociológica de este principio se encuentra en obras tan diversas como los Principles of Sociology de Giddins y los escritos éticos de Höffding. En ambos casos el concepto de simpatía se emplea esencialmente como un principio explicativo, aunque Höffding no interprete la simpatía tan formalmente como Giddins, cuya "conciencia de semejanza» (Bewusstsein des Gleichen) es una variante del principio de Smith.

Este principio introducido originalmente por Hume y Smith puede reconocerse también en otras formas de la psicología social moderna. Incluso la doctrina de aquellos autores que contemplan la imitación (Nachahmung) como la forma específica de la reacción sociológica puede ser considerada como una

22 Hume, Human Nature, II:335. «Podemos comenzar considerando nuevamente la naturaleza y la fuerza de la simpatía. Las mentes de todos los hombres son semejantes en sus sentimientos y operaciones, y nadie puede ser movido por cualquier afección a la que todos los demás no sean susceptibles de algún modo. Como si fueran cuerdas entrelazadas, la moción de uno cualquiera se comunica a los demás, de tal modo que, fácilmente, los afectos pasan, con rapidez, de una persona a otra y generan movimientos correspondientes en cualquier criatura. Cuando veo los efectos de la pasión en la voz y en el gesto de cualquier persona, mi mente pasa inmediatamente de los efectos a sus causas, y forma una idea tan viva de la pasión que enseguida se convierte en la pasión misma.»

Ibid., p. 350. «Este principio de la simpatía es de una naturaleza tan poderosa e insinuante que entra en la mayoría de nuestros sentimientos y pasiones y, a menudo, se produce bajo la apariencia de su contrario. Por esto es notable que, cuando una persona se me opone en algo de lo que estoy bien seguro y suscita por la contradicción mi propia pasión, tengo siempre un cierto grado de simpatía por ella, sin que mi conmoción proceda de otro origen. Podemos observar un conflicto evidente o un encuentro (Nota de los trads.: en el original aparece recounter) de principios y pasiones. Por un lado, está esa pasión o sentimiento que me es natural - y puede observarse que cuanto mayor es la pasión mayor es la conmoción- y, por otro, debe haber alguna pasión o sentimiento que no puede proceder más que de la simpatía. Los sentimientos de los otros no pueden nunca afectarnos si no se convierten en alguna medida en nuestros. En este caso, actúan sobre nosotros, oponiéndose a, o incrementando, nuestras pasiones como si en origen se hubieran derivado de nuestro talante y disposición. Mientras permanecen escondidos en las mentes de los otros nunca pueden tener influencia sobre nosotros; ni siquiera cuando son conocidos, si no fueran algo más que imaginación o concepción. Esa facultad está tan acostumbrada a los objetos de todo tipo que una mera idea contraria a nuestros sentimientos e inclinaciones nunca será, por sí sola, capaz de afectarnos.»

Dugald Stewart, III:116; HöfFding, Ethik, pp. 39, 57, 229; Giddings, Principles of Sociology, pref. a la 3.a ed., p. 11. Confróntese también GuYAU, L'irreligion de l'avenir, pp. 341, 346. 
adopción del principio de simpatía de Hume, pese a que no exista base para suponer una relación histórica entre ambas doctrinas ${ }^{23}$. Pues, de acuerdo con su nombre, la teoría de la imitación sólo explicaría la propagación, de una persona a otra, de un movimiento o modo de conducta espontáneos. Pero en realidad, los representantes de esta doctrina entienden por imitación lo mismo que Hume entiende por simpatía; a saber: la transmisión de un sentimiento o de una idea de un hombre a otro, de tal forma que el segundo, precisamente porque se pone en la situación espiritual del primero, reacciona ante el estímulo meramente imaginado, que de hecho solo correspondería al primero, como si él mismo hubiera percibido el estímulo ${ }^{24}$.

El uso que hacen Hume y Smith de la noción de simpatía no puede equipararse con el concepto que se encuentra posteriormente, sobre todo en Spencer y Höffding, y que identifica la reacción simpatética con instintos profundamente arraigados, como el amor maternal y otros ${ }^{25}$. Este "altruismo impulsivo», como lo llamó Baldwin, no debería confundirse con la imitación en el sentido en que usan este término Tarde y el propio Baldwin, ni con la simpatía en el sentido que le da Hume. Para Hume la simpatía es un concepto formal de mucho mayor alcance, que pretende explicar en general cómo podemos comprender los sentimientos y la vida interior de nuestros semejantes. Representa aproximadamente lo que Jodl denominó «la capacidad de reproducir los sentimientos ajenos» ${ }^{26}$. La diferencia entre Hume y los autores precedentes

${ }^{23}$ BALDWIn, Social and ethical Interpretations, prólogo a la 2.a ed., p. 12; TARDE, Les lois de l'imitation, p. 85, y études de psychologie sociale, p. 51; BAGEHOT, Der Ursprung der Nationen, p. 106.

${ }^{24}$ Hume, Human Nature, vol. II:111; SMITh, Moral Sentiments, p. 4; TARde, Les lois de l'imitation, Prefacio, p. 7.

${ }_{25}$ Höffding, Psychologie, p. 305, y Ethik, p. 608; Spencer, Psychology, II:558.

${ }^{26}$ JodL, Psychologie, II:329. "Si a la capacidad de reproducir los sentimientos ajenos se le llama, en general, "compasión" (Mitgefühl), hay que decir, entonces, que el desarrollo de los sentimientos personales se basa, en su mayor parte, en la compasión. Es necesario tener presente que, en este sentido, la compasión entra a tomar parte, como elemento, tanto en los sentimientos de lo propio como en los sentimientos de lo ajeno, y que es, por consiguiente, un concepto mucho más amplio que el de sentimiento por el dolor o por la alegría ajenos, que la costumbre - y por desgracia también, en la mayoría de los casos, la propia terminología científica - se limita a atribuir, en definitiva, a la compasión. Porque, en el sentido que aquí se adopta, la compasión no se da sólo cuando reproducimos en nosotros mismos el dolor y la alegría de otro sintiéndolos como algo propio. En la compasión se apoyan el agradecimiento y el amor con que convertimos la disposición de benevolencia de otra persona en nuestro propio ánimo; y se apoyan, asimismo, la alegría por las desgracias ajenas y la crueldad con que sentimos el dolor de otro porque es una pena suya y no nuestra, paladeándolo como una satisfacción de nuestro antipatía y malquerencia. En la compasión se apoyan ese orgullo y esa vergüenza nuestros, en los que reproducimos la admiración, la consideración y el respeto, o bien la burla, la aversión y el desprecio que los demás sienten hacia nuestra persona o nuestras obras, y los comparamos con nuestro amor propio. $\mathrm{Y}$ en el mismo sentido que se ha dicho que todos los sentimientos de lo ajeno se basan en el sentimiento de lo propio, puede decirse también lo contrario: que todo sentimiento de lo propio obtiene su alimento de la reproducción de los sentimientos de los otros, y que, sin ellos, se marchitaría irremediablemente. Por esta razón, parece aconsejable prescindir completa- 
reside, precisamente, en el hecho de que, para Hume, la simpatía ya no es exclusivamente un sentimiento como la compasión, la benevolencia, etc., sino que es, más bien, un proceso a través del cual se producen estos y otros sentimientos y disposiciones cargados de valor moral.

Partiendo de esa explicación, la diferencia entre simpatía e imitación ${ }^{27}$ parece residir menos en la naturaleza distinta de ambos procesos que en un énfasis unilateral en las distintas caras de un mismo y único proceso. A partir del tipo de explicación de ese proceso que es hoy usual, nos inclinamos a considerar el aspecto psicológico - o sea el consciente- como un fenómeno concomitante con el aspecto fisiológico. Esto contrasta con el planteamiento de Hume, quien, con los supuestos de la psicología racionalista de su época, consideraba la idea como causa, de tal modo que todo el proceso asumía un carácter psicológico, e incluso, en cierto sentido, también lógico ${ }^{28}$. Llámese a este proceso simpatía — con Hume — o imitación — con Tarde_-, lo esencial en su interpretación es siempre el énfasis que se pone en el aspecto formal. Es decir, estamos ante un proceso, y no ante un sentimiento con un contenido determinado. No se trata de intentar explicar el origen de los sentimientos e impulsos sociales, sino el modo como esos impulsos se influyen recíprocamente y se propagan, dándose por supuestos los impulsos humanos como se han desarrollado en la historia.

Aunque la imitación tomada como proceso de comunicación es un objeto muy discutido en las nuevas investigaciones psicológicas, hasta ahora éstas no han conducido a un concepto unívoco. No sabemos todavía con exactitud qué es lo que de hecho tenemos que entender por imitación ${ }^{29}$.

mente del empleo de un término como el de "compasión", que se malinterpreta con facilidad, y usar, en su lugar, la expresión "simpatía" — acuñada por la psicología inglesa de los siglos anteriores - para los fenómenos de reproducción de los sentimientos que están aquí en cuestión. El uso que de ella hicieron Hume y Smith, a quienes la ciencia debe la primera investigación penetrante $-\mathrm{y}$ que sigue siendo fundamental hasta hoy - de los fenómenos en cuestión, cubre lo que aquí se entiende por "compasión» en su sentido más general.»

Véase también Hume, Human Nature, II:112, 335, 350.

27 TARDE, Études de psychologie sociale, p. 291.

${ }^{28}$ Confróntese C. Lange, Ueber Gemütsbewegungen; James, Principles of Psychology, II:442.

29 Véase BALDwin, Dictionary of Philosophy and Psychology, donde se presentan y explican los diversos significados de imitación de acuerdo con diversos autores. Confróntese también los escritos de TARDE, BALDWIN y otros que se han mencionado ya. Véase también EpINAS, Des Sociétés animales, pp. 358 ss.; RoyCE, "The External World and Social Conciousness», Philosophical Review, III (septiembre 1894): 513-545; DurKhEIM, Le suicide, cap. IV; BOSANQUET, Mind, abril 1898; Dewey, Philosophical Review, julio 1898; Lloyd Morgan, Animal Behaviour, cap. V; Wallace, Natural Selection, cap. VI; Groos, Das Spiel der Menschen, 2. a parte, cap. III; Giddings, Inductive Sociology, p. 105, y The Principles of Sociology; PreYer, Die Seele des Kindes, 2. ${ }^{\text {a }}$ parte, cap. XII. 
No queremos entrar en una consideración específica del proceso de imitación como tal, pero, en todo caso, es preciso indicar tanto la diversidad de las funciones sociales que dicho proceso desempeña, como la diversidad de formas que adopta en los distintos grupos sociales. Podemos hacerlo adecuadamente sin tener que ocuparnos específicamente de la imitación como proceso psicoló$\operatorname{gico}^{30}$.

Para comenzar, vemos que en los animales más desarrollados la imitación es un medio principal para un ulterior desarrollo y determinación de las disposiciones heredadas, es decir, de los instintos ${ }^{31}$. En este caso, la imitación se muestra como una conducta de tipo instintivo. Incluso, cabalmente, como un movimiento reflejo, como ocurre por ejemplo con el contagio, frecuentemente observado, del bostezo. Sólo cabe explicar esta acción instintiva porque ya existe la disposición al bostezo. El hecho de ver la acción simplemente proporciona el impulso incitador que libera el movimiento imitativo.

La disposición del organismo psico-físico hacia la sugestión es característica en esta primera forma de imitación. Los animales sólo imitan aquellas acciones para las que les ha dispuesto la herencia ${ }^{32}$. Al tipo de comportamiento que se transfiere de una generación a otra por imitación se llama tradición. A partir de ahí la tradición se opone al instinto, que los animales reciben sólo a través de la herencia. Por eso, cuando se habla de una tradición animal, se hace

30 ROYCE ofrece una explicación clara y sencilla sobre la importancia sociológica de la imitación en su artículo "Self-consciousness, Socialconsciousness, and Nature». Véase Studies of Good and Evil, p. 219. "Desde la infancia, los actos expresivos de mis semejantes tienen, para mí, un significado como sugerencia de su vida interior concreta, precisamente en la medida en que soy capaz de imitar esos hechos suyos mediante actos corporales míos que se realizan bajo condiciones semejantes a aquellas en las que actúa mi semejante. Porque, cuando repito definidamente un acto corporal que expresa cualquier significado humano, el acto adquiere para mí, cuando lo repito en determinadas condiciones, un significado interior que nunca podría captar si lo observara simplemente desde fuera, como un acontecimiento en el mundo fenoménico que percibo. Pero ese significado interior que el acto adquiere cuando lo repito se convierte, para mí, en el significado objetivo del acto que realiza mi semejante; y, de este modo, el significado del acto imitado, que yo interpreto en el momento de la imitación, es concebido como el significado real, como la experiencia interior de mi semejante en el momento en que realiza el acto que es mi modelo. Si usted se ríe, sé lo que quiere significar precisamente en la medida en que, bajo condiciones semejantes, yo puedo unirme a usted y reír de buen grado, y entonces, al imitar totalmente su acción, obtengo un sentido de su significado. Pero si yo le veo a usted reír en circunstancias que me prohiben en absoluto incluso concebirme imitando su expresión de júbilo, entonces, debo decir francamente que no entiendo en absoluto lo que usted quiere decir al reír en esa situación precisa, y no puedo, por tanto, concebir cuál es su experiencia interior.»

31 Romanes, Geistige Entwicklung im Tierreich, pp. 238 y ss.

32 Lloyd Morgan, Animal Behavior, p. 189. «Es probable que la imitación en los animales tenga su fundamento en la conducta instintiva, que puede ser considerada como el tipo de conducta característicamente social de ellos. Si en un grupo de polluelos uno aprende por experiencia casual a beber de un bote de agua, otros le seguirán y picotearán en el agua y así aprenderán a beber. Una gallina enseña a sus polluelos a comer el grano u otro alimento picoteando en el suelo y dejando caer materiales adecuados para ellos, mientras que aquellos, al parecer, le imitan tomando el grano.» 
referencia a aquellos tipos de comportamiento adquiridos por transmisión, como el canto y la construcción de nidos en el caso de los pájaros, que no se heredan sino que se aprenden por imitación ${ }^{33}$.

En los seres humanos notamos un efecto de imitación similar. La gente aprende a hablar y adquiere otros usos y costumbres sociales mediante cierto tipo de sugestión semiconsciente o refleja ${ }^{34}$. La cantidad de comportamiento aprendido de este modo es muy superior en los seres humanos, la tradición animal es muy pobre comparada con la humana. Por contra, comparativamente, los instintos son más numerosos en los animales que en los seres humanos ${ }^{35}$.

Sin embargo, sería un error suponer que toda la significación sociológica de la imitación consiste en servir de medio para transmitir la tradición de una generación a otra. Es necesario considerar el gran número de sugestiones reflejas y sensomotoras con las que se afectan recíprocamente los miembros de un grupo en todo momento ${ }^{36}$. La consecuencia de esto no es sólo que los usos y

${ }_{33}$ Ibid., pp. 220 y ss.

${ }^{34}$ Ibid., pp. 221 y ss. «En primer lugar, es probable que, como en otros modos de conducta animal, el procedimiento tradicional se fundamente en una base instintiva. Esta debe ser una tendencia imitativa del tipo general siga-al-líder. Cuando esta tendencia instintiva está sólo especializada parcialmente o de modo incompleto de acuerdo con ciertas líneas de conducta, tendríamos en esta etapa ciertas tendencias de acción hereditarias, dependientes de estímulos aportados por la conducta de los otros.»

${ }^{35}$ Ibid., p. 176. «Podemos llamar capacidad innata a este fondo de acomodación inteligente, a esta capacidad heredada de hacer frente a circunstancias especialmente difíciles cuando surgen. Dada la naturaleza del caso debe ésta ser indefinida, porque debe llevar consigo la capacidad de hacer frente a las combinaciones imprevistas de las fuerzas del entorno mediante nuevas combinaciones de los resultados de la experiencia. Su marca distintiva es la plasticidad frente a la fijeza estereotipada del instinto típico. Y acompañando a su evolución hay probablemente, como hemos visto, una disolución de su antítesis: el instinto. Así, podemos dar razón del hecho de que el hombre, con su gran depósito de capacidad innata, tiene un número tan reducido de instintos estereotipados.»

${ }^{36}$ C. LANGe, Sinnengenüsse und Kunstgenuss, p. 43. "Hay que tener claro que la interpretación, mediante el ojo y el oído, del síntoma corporal de una emoción es capaz de provocar inmediatamente - sin que intervenga ningún eslabón anímico intermedio- los mismo fenómenos que observamos. Considerado desde el punto de vista fisiológico, el asunto es, sin duda, muy notable o, en otras palabras, muy oscuro. De todos modos, no se trata de un fenómeno aislado, sino que, por el contrario, nos encontramos en este caso con la expresión singular de un amplio fenómeno psico-fisiológico de gran importancia: el involuntario impulso instintivo que todo hombre tiene de imitar inmediatamente el movimiento o la voz que detecta. Esto se produce mediante la imitación del movimiento muscular, como en cualquier otra imitación simpatética. El hecho de que este impulso imitativo no desempeñe un papel importante en nuestra vida, de que no corramos continuamente detrás de los demás remedándonos unos a otros, se debe a que tenemos el empeño contrario de dominar y someter este impulso; pero también a la circunstacncia de que dicho impulso imitativo se hace valer preferentemente ante fenómenos muy pronunciados y que son atentamente observados.»

BALDWIN, Mental Development, cap. VI, distingue entre sugestión fisiológica (refleja), sensomotora e ideomotora. La imitación simpatética, de la que habla Lange aquí, es un tipo de sugestión sensomotora. 
las formas de conducta, una vez aprendidos, se fortalezcan con nuevas sugestiones, sino que, además, los individuos se encuentren continuamente bajo una especie de coacción espiritual que puede ser considerada como la suma o el resultado de la interacción de todas estas sugestiones recíprocas. Vemos también que, a través de su continuo ejercicio, el uso social adquiere la forma de costumbres individuales, arraiga en el organismo psico-físico ${ }^{37}$. Una vez arraigadas, se practican con un sentimiento de obligación tal que, ante cualquier transgresión por parte de los otros, se reacciona con indignación. Vemos, por tanto, un momento esencial del proceso sociológico en que el grupo como un todo ejerce coacción sobre el individuo ${ }^{38}$.

Spencer reunió las diversas formas de interacción cuya consecuencia es esa dominación (Beherrschung) directa de la colectividad sobre los individuos, bajo la expresión "constricción ceremonial» (ceremonial control). Pensaba que tal constricción ceremonial es la forma más primitiva y general en la que, en suma, se ejerce la dominación (Herrschaft) ${ }^{39}$. Todas las formas elementales de las constricciones sociales se traducen luego en costumbres sociales que se mantienen por la influencia sugestivo-refleja que los individuos ejercen entre sí dentro del grupo. Todas las formas subsiguientes de dominación se basan en ellas.

Al querer comparar la sociedad animal y la humana se manifiestan claramente diferencias fundamentales que hay que considerar aquí, aun cuando la interacción que observamos en los animales se acomoda en términos generales a lo que estamos diciendo.

Cuando los animales entran en el mundo poseen un conjunto de instintos

37 WundT, Ethik, I:108-128, ha distinguido claramente entre costumbre (Gewohnheit), hábito ético (Sitte) y usos (Gebräuche).

${ }^{38}$ Durkheim, Revue Philosophique, mayo 1894, pp. 466 y ss. (Nota de los trads.: se trata de una referencia a la primera parte del artículo "Les régles de la méthode sociologique», vol. 38, pp. 465-498 y 577-607, que constituyó la base del famoso libro de Durkheim, publicado en 1895 con el mismo título); Ross, Social Control, p. 146.

39 SPEnCER, The Principles of Sociology, II:5. «Esta constricción ceremonial, que precede a otras formas de constricción, sigue siendo siempre la forma más ampliamente difundida de constricción, como hemos mostrado con hechos que se producen en el tráfico entre los miembros de cada sociedad, como el de que las acciones decisivas de gobierno, usualmente, tienen como prólogo ese gobierno de las observancias. La embajada puede fracasar, la negociación puede ser interrumpida por la guerra, la coerción que una sociedad ejerce sobre otra puede establecer un régimen político más amplio con sus órdenes perentorias, pero habitualmente existe esa regulación de la conducta, más general y vaga, que precede a la más especial y definida. De tal modo que, dentro de una comunidad, los actos de control relativamente rigurosos procedentes de las agencias de regulación, civiles y religiosas, comienzan y son cualificadas por ese control ceremonial, que no sólo inicia, sino que, en cierto sentido, envuelve a todos los demás... Las formas de acción modificada producidas en los seres humanos por la presencia de sus semejantes, constituyen aquel control, comparativamente difuso, del que surgen otras formas de control más definidas: el tipo de gobierno, primitivamente indiferenciado, a partir del cual se diferencian los gobiernos políticos y religiosos y en el cual estos permanecen siempre inmersos». (Nota de los trads.: la expresión ceremonial control aparece en inglés en el original, como aclaración del sentido de la versión alemana —zeremonielle Einschränkung — que propone el propio Park). 
que trazan y determinan completamente sus disposiciones y las formas de comportamiento que se basan en ellos. En consecuencia, la cantidad de conducta nueva que pueden conseguir los animales está limitada por el grado de forma instintiva que tengan sus disposiciones heredadas ${ }^{40}$. Además, las propias disposiciones que todavía no estén determinadas al nacer, quedarán enseguida fijadas como costumbres. Por eso, en los animales todo impulso parece llevar inmediatamente a una acción predeterminada, y además del mismo modo para cualquier individuo de la misma especie. Los animales manifiestan relativamente poca individualidad. Los objetos que entran en su horizonte de atención tienen siempre un mismo significado para todos los individuos de la misma especie. Ocurre de modo diverso con los seres humanos, cuyas acciones instintivas son relativamente pocas y cuya conducta adquirida es relativamente amplia. Lo que se sigue de ahí es que para los seres humanos el significado de cada estímulo no está predeterminado. Tienen, por contra, que aprender primero, a través de la experiencia, cómo reaccionar ante los diversos estímulos. Más aún, precisamente porque la experiencia de cada individuo difiere de la de sus semejantes, el significado del mundo exterior es distinto para cada individuo.

Con esto se relaciona el hecho de que las acciones humanas no siempre están dictadas por motivos inmediatos, sino que constantemente - y en mayor o menor medida - se conducen por ideales. Esto hay que explicarlo, en primer término, por la capacidad que tienen los hombres de concebir ideales. El mundo se hace infinitamente más complicado tan pronto como se puede comparar lo que es con lo que fue. Además, los seres humanos poseen la capacidad de comunicar sus pensamientos y sentimientos en un grado mucho mayor que los animales y, en consecuencia, el mundo en el que viven los hombres contiene una multiplicidad de significados que el mundo de los animales no puede tener. Mediante la interacción recíproca, las disposiciones de los hombres se alteran continuamente $y$, de ese modo, todo su ser gana cierta plasticidad. Cuanto más móviles sean los individuos y mayor sea el número de movimientos voluntarios e involuntarios que sean capaces de hacer, tanto más múltiples y diversos serán los significados de los objetos a los que se dirigen esas acciones $^{41}$.

Ahora bien, cuando pensamos que el hombre ha perdido parcialmente la cualidad de la inmediatez, nos referimos sólo a que no reacciona a todo estímulo, y a que no obedece a cada impulso como si el significado total que el mundo pudiera tener en ese instante estuviera contenido en dicho impulso. Los seres humanos se muestran, antes bien, mucho más inclinados a considerar cada experiencia como resultado de otra previa y como signo de otra posterior.

40 Wund, Ethik, I:107 ss.

${ }^{41}$ MünSterberg, Grundzüge der Psychologie, p. 551. "Comprender un objeto significa que adoptamos un determinado tipo de acción» (...) «el tipo particular de actitud motora es la base del tipo particular de comprensión. Por tanto, el significado de una palabra puede comprenderse únicamente como una actitud motora.» 
El significado pleno de un objeto representado no reside en el impulso que despierta inmediatamente, sino que lo obtiene sólo al ser entendido en sus relaciones; al corregir el primer impulso con los asociados a él. De esta manera, el mundo de los seres humanos adquiere una doble significación, una inmediata y otra mediata. Esta doble significación de los objetos, por la que cualquier otro objeto no sólo tiene una significación inmediata e individual, sino que también es contemplado como signo y símbolo de otros objetos y otros significados, pertenece en exclusiva al mundo de los seres humanos, distinguiéndolo del de los animales.

Precisamente porque los seres humanos no se rinden incondicionalmente a cada impulso — siempre dirigen sus acciones, en mayor o menor medida, de acuerdo con motivos ideales - a partir del mundo de las percepciones que es diferente para cada individuo surge un mundo de ideas que es idéntico para todos los individuos. Esta separación no la encontramos en la conciencia animal. Los animales se mueven siempre en un mundo de percepciones ${ }^{42}$. El significado de cada objeto se establece en el momento de la percepción, en lugar de asignarse de inmediato cuando el objeto encuentra su sitio en un orden ideal. En los animales la percepción es seguida inmediatamente por la acción correspondiente. Por ello, la interacción entre los animales aparece como una transferencia directa del movimiento de un individuo a otro. En una manada sólo se imitan aquellos movimientos que se manifiestan con el carácter de un reflejo, como la expresión de sentimientos, el grito de peligro, etc. El movimiento de imitación tendrá el mismo carácter que el imitado. Todo el proceso sociológico presupone la existencia en los miembros de la manada de disposiciones totalmente conformes y recíprocamente complementarias que se activan por la recíproca influencia sugestiva que ejercen los movimientos semejantes de unos sobre otros ${ }^{43}$.

Entre los seres humanos existe un tipo similar de interacción recíproca. Cada generación ha tomado de esa forma directa una buena parte de sus tradiciones de la generación precedente. El habla, los usos, y todo el aspecto ceremonial de la vida social cotidiana, los hemos aprendido por medio de una imitación de nuestros semejantes sólo parcialmente consciente. Estamos predispuestos por herencia para el habla y para las demás funciones sociales, y el cultivo de esas funciones se produce a través de la imitación espontánea de las for-

42 Calderwood, Evolution and Man's Place in Nature, p. 124. «La sensibilidad en el organismo, la sucesión de impresiones sensoriales en la historia de la vida y la correlación de estas con la actividad a través de los centros nerviosos, son características de toda vida orgánica, incluyendo tanto la del insecto como la del ser humano. ¿Qué es entonces lo peculiar del ser humano? Su discriminación racional previa a la discriminación sensorial. Todo organismo siente el contacto y responde a él. Toda vida humana no sólo hace estas dos cosas, sino que también interpreta la experiencia, formando de ese modo un conocimiento de las cosas con las que el organismo sensible entra en contacto."

Confróntese ROMAnES, Die geistige Entwicklung beim Menschen, pp. 21 y ss.

43 Lloyd Morgan, Animal Behaviour, cap. V. 
mas sociales circundantes. Como los seres humanos no se comprometen totalmente en sus actos particulares, sino que abrigan intenciones secundarias y consideran la acción emprendida como un medio para alcanzar la meta preconcebida, no están sometidos al dominio de ese proceso de interacción del mismo modo que los animales. Los hombres pueden ceder a la coacción que la colectividad ejerce sobre el individuo y someterse a las costumbres del grupo y, no obstante, seguir permitiendo que sus acciones estén regidas por motivos completamente individuales. El individuo puede incluso emplear ese mecanismo socio-psicológico, preestablecido por los usos y las formas de acción social, como un medio para conseguir su fin personal. Esto sucede, de hecho, todos los días cuando nos servimos de la organización social para el logro de nuestras metas particulares. En la organización económica de la sociedad encontramos una forma social en la que cualquier otro individuo de la colectividad aparece solamente como un medio para el logro de la felicidad individual de otro. La economía política clásica ha interpretado la sociedad precisamente desde esta perspectiva.

Como ya señaló Simmel, el trueque es también «una configuración sociológica sui generis, una forma y una función originaria de la interacción social». Podemos añadir que sólo se da entre los hombres ${ }^{44}$. El trueque se presenta como una forma secundaria de interacción que se ha tratado de incluir bajo el concepto de imitación. En este caso ocurre que una persona utiliza el mecanismo psicofísico del habla para situarse en la vida interior del otro, aunque actuando en sentido contrario. Consideraremos el caso de la relación de trueque más adelante. Lo que hay que subrayar ahora es que la forma primitiva de interacción observada en la manada animal también está continuamente activa en los grupos humanos, puesto que existe una uniformidad del aspecto formal de la vida social que se manifiesta en la costumbre y en la moda y que obliga a todos los individuos. Esta uniformidad es como puramente formal y externa y pierde significación cuanto más se alejan las formas sociales de las formas «naturales» de los animales.

Por consiguiente, vemos que en la vida social, en la vida cultural, se advierte que la imitación sugestiva - la forma primaria de la interacción — sólo determina el estilo de vida, pero no la vida en sí misma.

En general, la noción de «interacción primaria» que acabamos de emplear coincide con lo que Tarde entendía por «imitación». De hecho, Tarde entendía que la imitación no era más que un tipo especial de la "repetición universal», cuyo carácter específico consistía en que permite que las formas de acción creadas por individuos geniales se extiendan y se generalicen en la sociedad. Lo

${ }^{44}$ Simmel, Philosophie des Geldes, p. 56. 
específicamente social es, precisamente, lo que de este modo se crea y se extiende por la sociedad ${ }^{45}$.

A partir de ahí se explica el que paraTarde la vida social aparezca trivial y carente de significación en contraposición con la vida de los individuos que actúan en ella. Puesto que piensa que todo lo que las grandes masas repiten de un modo tan mecánico, la vida social será siempre superficial y carente de significación.

El concepto de imitación de Baldwin es esencialmente distinto del de Tarde. Para Baldwin la importancia de la imitación no está en que la misma acción la repitan todos los miembros del grupo, ni en que esa forma de acción se difunda en una multitud de individuos. En lugar de eso, la imitación es importante para él como un medio por el que la vida interior de los individuos influye en la de los demás, y porque sobre la base de ese tipo de interacción se desarrollan las personalidades ${ }^{46}$. La significación de la imitación considerada como una función social no reside en el lado externo y formal de la acción que se repite por medio de ella, sino, más bien, en la repercusión recíproca de esa acción repetida en el ánimo de los individuos, es decir, en las nuevas disposiciones que, de ese modo, provoca en ellos ${ }^{47}$. Baldwin consideraba el proceso de la imitación solamente desde el lado del individuo y, al hacerlo, descubrió la tarea específica que distingue a la psicología social de la sociología. Tenemos ahora que tratar ese mismo proceso desde la perspectiva del grupo, desde el ángulo sociológico ${ }^{48}$.

En ciertas agrupaciones sociales, como el parlamento o el tribunal, se observa un cierto tipo de interacción cuya función no es la de llevar a cabo una acción colectiva, sino que se orienta, única y simplemente, a dirigir la acción colectiva, libre de cualquier tipo de conducción externa, hacia un cambio de disposición del propio grupo o de alguno de sus miembros. Este tipo de instituciones, como el parlamento y el tribunal, ofrecen, por tanto, ejemplos de funciones formales con las que la colectividad influye sobre sí misma.

Los procesos en los cuales el grupo social comparece determinándose a sí mismo difieren esencialmente de los que hemos encontrado en las manadas animales; y también difieren de los procesos imitativos que Tarde ha apuntado

45 TARDE, Les lois de l'imitation, p. 76. "Una sociedad es siempre, en grados diversos, una asociación; y una asociación es a la socialidad, a la imitatividad, por decirlo así, lo que la organización es a la vitalidad, o incluso lo que la constitución molecular es a la elasticidad del éter... Partiendo de eso, si quisiéramos mantener la analogía en los tres reinos, sería necesario ver que la vida es simplemente la organización de la irritabilidad del protoplasma, y que la materia es simplemente la organización de la elasticidad del éter, de la misma manera que la sociedad no es otra cosa que la organización de la imitatividad.»

Confróntese TARde, Psychologie Économique, I, pp. 7 y ss., y BALDWIn, Social and Ethical Interpretations, p. 496.

${ }_{46}$ BALDWIN, Social and Ethical Interpretations, $1 .^{\circ}$ parte, cap. I, "The imitative person».

${ }^{47}$ Ibid., pp. 539 y ss.

48 Ibid., p. 531; TosTI, «Social Psychology and Sociology», Psychological Review, julio 1898, p. 547. 
en sus obras. Podemos considerar el proceso de imitación de Tarde como una función sociológica comparable con el proceso de asociación de la psicología individual, en el que las disposiciones ya adquiridas por el grupo parecen guiar el curso normal del proceso interindividual. Sin embargo, tenemos que decir al respecto que el proceso del que nos ocupamos aquí se parece más a los procesos de atención o de percepción. En efecto, esos casos señalados del parlamento y del tribunal sólo pueden considerarse en lo esencial como un ajuste y una adaptación del grupo como un todo a una situación. No se trata, por tanto, de una acción en el sentido usual de la palabra, sino tan solo de la preparación de una acción.

Los procesos sociológicos que vemos en juego en la acción de un parlamento o de un tribunal son ciertamente característicos, pero mucho más evolucionados y complicados y, por tanto, mucho más difíciles de analizar que otros procesos similares que pueden observarse en otros grupos. La forma más simple del proceso que tratamos la podemos observar con la mayor claridad en la masa. Al respecto tenemos que traer a consideración que el término "masa", entendido en el sentido de la psicología colectiva, como se usa aquí, no puede equipararse a las hordas errantes semejantes a las manadas animales, ni a las multitudes atrapadas por el pánico, que son lo más parecido a las manadas de animales ${ }^{49}$.

La masa debe ser considerada más bien como el resultado de un proceso sociológico específico que posee las propiedades generales de un proceso de atención. Encontramos un ejemplo de atención social cuando un gran número de individuos se paran en una calle transitada para contemplar el paso de un desfile o para oír al orador de la esquina. Ejemplos aun más llamativos del mismo proceso sociológico pueden verse en el efecto de la publicidad moderna, cuyo arte se reduce al dominio del mecanismo mediante el cual se dirige la atención. Precisamente, este ejemplo ilustra con claridad que estamos ante un proceso sociológico que no puede considerarse simplemente como una mera suma de los procesos psicológicos individuales: al hacer publicidad, la influencia intencional genera mucho más la interacción entre los individuos que la sugestión directa.

Un tipo más o menos definido de atención social está siempre presente donde hay hombres reunidos. En el mundo más amplio de la política y en el pequeño mundo de la vida íntima de la sociedad están siempre presentes ciertos intereses generales que dominan nuestros pensamientos y nuestra conversación. Hoy, la guerra de Asia; el año pasado, Inglaterra y los Boers; y anteriormente el «affaire» Dreyfus, que cautivó la atención de todo el mundo.

${ }^{4} 9$ El pánico es una forma social que todavía no ha sido tratada por la psicología colectiva. Una descripción del pánico se encuentra en Max WIRTH, Geschichte der Handelskrisen. Confróntese también SIDIS, Psychology of Suggestion, pp. 343 y ss., y STOLL, Suggestion und Hypnotismus, pp. 450 y ss. Hay una tendencia continuamente recurrente entre los diferentes autores a considerar la masa como un concepto histórico más que como una noción puramente científico-natural y, por tanto, atemporal. Véase Sighele, Psychologie des sectes, p. 37. TARde, Psychologie pénale (Nota de los trads.: Philosophie pénale en el original), y Sidis, Psychology of Suggestion, p. 310. 
Por consiguiente, la atención social se presenta como un proceso en el que un grupo influye sobre sí mismo; es decir, como un proceso donde el grupo adopta una posición acerca de algo que sucede en su entorno. Este está en directa contraposición con los procesos descritos anteriormente, que permiten que los usos sociales se establezcan y perpetúen en la sociedad. Y lo está, precisamente, porque es a través de la atención colectiva como las costumbres y las formas más estables del tráfico social se debilitan y finalmente se descomponen. Donde mejor se ve esto es en la masa, en la que la atención social cobra una expresión más intensa de lo habitual. Dondequiera que se desarrolle la conciencia de masa, ya se trate de una aglomeración humana que circula por una calle, o de un pueblo entero, vemos que el curso habitual de la vida social se interrumpe y la función social normal se perturba. En momentos de gran agitación, no sólo se desmoronan los límites impuestos por la ley, sino también la tradición y el hábito ético (Sitte) ${ }^{50}$.

El primer efecto de esta atención intensificada es la represión de los impulsos y de las asociaciones normales, que redunda en un acrecentamiento de la sugestibilidad. Esa sugestibilidad intensificada es, precisamente, la propiedad característica de la masa. Sidis advirtió al respecto que tenemos que distinguir dos etapas en el desarrollo de la conciencia de la masa. En la primera etapa, la sugestibilidad del grupo se acrecienta por sugestión «indirecta». La sugestibilidad aumenta cada vez más hasta que alcanza finalmente una condición comparable a la hipnosis. Esta es, justamente, la segunda etapa: la masa llega a una situación en la que al final reacciona ante la sugestión «directa», a menudo con la impulsividad de quien está en estado hipnótico. En esta fase la masa aparece como plástico instrumento de su líder, que lleva a efecto, sin resistencia alguna sus sugestiones. En ese momento la masa se transforma en un disturbio popular ${ }^{51}$.

50 Dr. Friedmann, Wahnideen im Völkerleben, p. 259; Le Bon, Psychologie du socialisme, p. 93; Lombroso, Die Anarchisten, p. 21; Förstemann, Die christliche Geisslergesellschaft, p. 43. STOLL, en Suggestion und Hypnotismus in der Völkerpsychologie, informa del efecto de las Cruzadas como sigue: «La idea de las Cruzadas absorbió todos los demás intereses. El entusiasmo que suscitaron enmudeció toda lucha política, e incluso los vínculos de la vida familiar fueron sacrificados a ellas de buen grado. Los moradores de los claustros dejaron sus tranquilas moradas, los ermitaños sus bosques y desiertos, para entrar en las filas de los cruzados. Hasta los ladrones y salteadores dejaron sus guaridas para confesar sus fechorías y, como penitencia, abrazar la cruz y partir para Tierra Santa. Los mercaderes, artesanos y campesinos perdieron los oficios de los que vivían; lo que no podía llevarse en el viaje perdió su valor y se vendió a bajo precio a los que quedaban atrás. El precio de la comida bajó tanto que había excedentes en medio del hambre. Milagros y diversos tipos de signos celestiales intensificaron la locura general... Las gentes que inicialmente se habían burlado del ajetreo de los cruzados resultaron también atrapadas y transformadas gradualmente por el torbellino general (algo especialmente característico del efecto imitativo de la sugestión): lamentando su indiferencia inicial, la reemplazaron por un celo que no fue menos intenso que el éxtasis de aquellos de los que se habían reído antes. La agitación general mantuvo ocupadísimos a todos los espíritus, de tal modo que incluso en aquellos tiempos de inseguridad política y pública, los robos, los asaltos generalizados, y los incendios homicidas que tan frecuentes eran, cesaron sin ningún esfuerzo por parte del gobierno.»

${ }^{51}$ Sidis, Psychology of Suggestion, pp. 18 y ss. y 297 y ss. 
Precisamente porque se comprueba que es un poder social cuyo efecto siempre es más o menos perturbador y revolucionario, rara vez surge la masa donde hay estabilidad social y donde las costumbres tienen raíces profundas. Sin embargo, allá donde se eliminan los vínculos sociales y se debilitan las antiguas instituciones, se desarrollan con mayor facilidad y rigor grandes movimientos de masas. Desde una perspectiva sociológica esto explica, al menos en parte, la significación de la huelga. La huelga es un movimiento cuyo primer objetivo es conducir la atención del público hacia una situación considera injusta e insoportable por los trabajadores. Es una llamada al juicio de la colectividad porque ningún tribunal tiene jurisdicción en el asunto. Y, por consiguiente, proporciona las condiciones para un movimiento de masas y, eventualmente, para un motín popular.

Se ve cómo los grandes movimientos de masas de la Edad Media, las Cruzadas y los movimientos más pequeños que precedieron y acompañaron a la Reforma surgieron en momentos en los que los vínculos sociales se habían relajado y había desaparecido de la sociedad el espíritu colectivo ${ }^{52}$. Precisamente a través de estos movimientos de masa fue como se desarrolló un nuevo espíritu colectivo. El Renacimiento sucedió directamente a las Cruzadas. De las ruinas de la Iglesia surgieron nuevas sectas ${ }^{53}$.

Los movimientos de masas aparecen en este caso en un doble papel: fueron las fuerzas que destruyeron definitivamente las viejas instituciones existentes y las que introdujeron el espíritu de las nuevas. Este doble papel lo señaló Le Bon al decir que la masa se manifiesta al comienzo y al final de un desarrollo cultural $^{54}$.

Una descripción más atenta de ese proceso de atención social muestra que generalmente debe considerarse como un proceso represivo. Dentro de los límites de un grupo social, los ánimos operan reprimiéndose unos a otros. Le Bon y Sighele advirtieron que con el desarrollo de la conciencia de las masas se suprimen los impulsos motores propios del individuo, pero que, al mismo tiempo, se intensifican los impulsos motores comunes a todos los individuos ${ }^{55}$.

Este fenómeno se explica del modo que sigue. Sabemos ya que las emociones son muy contagiosas, especialmente cuando hay un gentío reunido, como ocurre, por ejemplo, en un mitin político. En tales circunstancias la excitación emocional de cada individuo se extiende a todo el grupo por un

52 Hecker, Der schwarze Tod, p. 42; SCHMidt, Histoire de la secte des Cathares ou Albigeois, I, pp. 59, 142; LipPerT, Christentum, Volksglaube und Volksbrauch, p. 574; FÖRSTEMANn, Die christliche Geisslergesellschaft, p. 19; SYMONDS, Renaissance in Italy, vol. I, "The Age of the Despots», cap. VII y apéndice IV; TAINE, L'ancien régime, libro V, cap. IX-2.

53 ADler, Geschichte des Sozialismus und Kommunismus, 1. a parte, libro III, "Kommunismus und Anarchismus als konsequenzen christlich-reformatorischer Tendenzen». Vid. especialmente cap. 2, pp. 91 y ss.

${ }_{54}$ LE BON, Psychologie des foules, p. 188.

55 LE BOn, Psychologie des foules, p. 17, y Sighele, Psychologie der Massenverbrechen, pp. 12 y SS. 
proceso involuntario de imitación. Allí donde la atención de todos se dirige hacia el mismo objeto, se observa un tipo de interacción que adopta la forma de un movimiento circular. Baldwin entendió la imitación ante todo como un proceso circular; como un proceso donde un organismo, al haber recibido un estímulo, intenta disponerse para poder recibirlo de nuevo y, así, sucesi$v_{\text {vamente }}{ }^{56}$. La forma más simple de este proceso circular existe en el heliotropismo de las plantas, que muestran una disposición a orientarse en la dirección de dónde reciben un estímulo agradable o vitalmente útil ${ }^{57}$. En las formas superiores este proceso circular se expresa como un proceso de atención ${ }^{58}$.

Un proceso circular de ese tipo se produce, en definitiva, en el ámbito sociológico, cuando dos individuos se imitan recíprocamente. Esta situación puede adoptar la forma sencilla de A imitando a B, y de B imitando después a A. En la medida en que se trata de expresión de emociones que se imitan de ese modo, B recibirá de A un reflejo de sus propios sentimientos. Entonces ambos están implicados en un proceso circular donde cada uno, al imitar al otro, aumenta su propia estimulación. El mismo proceso se da, de forma más complicada, cuando A imita a B, B imita a C, y C imita a A.

Si todo este proceso se entiende como un proceso represivo, la represión que se produce en la primera imitación se intensifica en las siguientes imitaciones. Esto dura mientras la atención de todos está dirigida hacía el mismo objeto, porque cada emoción de $\mathrm{A}, \mathrm{B}$ y $\mathrm{C}$ da lugar a que el individuo reciba más del mismo estímulo.

Las represiones que acompañan a cada imitación sucesiva introducen una condición de sugestionabilidad en el grupo. Sugestionabilidad, sin embargo, significa lo mismo que atención y, por consiguiente, tal proceso puede calificarse como un proceso de atención social ${ }^{59}$.

Por lo dicho antes, resulta claro que el desarrollo de una masa implica un proceso por el que los individuos, involuntariamente y sin premeditación alguna, se reúnen formando una unidad. La unidad de la masa se basa en el hecho de que todos los miembros del grupo están dominados por un único impulso común producido por la interacción recíproca de esos miembros. Esta interac-

56 Baldwin, Mental Development in the Child and the Race, p. 133. "Lo esencial en la imitación, entonces, más allá de una simple sugestión ideo-motora, es que el estímulo comienza un proceso motor que tiende a reproducir el estímulo y, a través de él, de nuevo el proceso motor. Desde el punto de vista fisiológico tenemos actividad círcular: realidad, imagen, movimiento; realidad, imagen, movimiento, etc.»

57 BaLDWIN, Mental Development, p. 180.

58 STOUT, A Manual of Psychology, p. 271.

59 Münsterberg, Grundzüge der Psychologie, p. 550. 
ción consiste en un proceso represivo que somete todos los impulsos puramente individuales, de forma que las únicas asociaciones que permanecen activas en la conciencia del individuo son las relacionadas con las ideas determinadas por el proceso de interacción. Si es característico de la masa que todos sus miembros estén dominados por un impulso común, y que todos los impulsos e intereses puramente individuales se repriman, es, en cambio, característico del público que los impulsos e intereses individuales se obtengan del fondo indeterminado de la conciencia colectiva y que se desarrollen, además, en una relación recíproca peculiar.

Antes de examinar con mayor atención la noción de público, tenemos que tener claro cómo se cumple esa relación recíproca entre los intereses que se presentan en el público. Dentro de la colectividad social estos intereses en interrelación recíproca están representados por grupos como los partidos políticos, las escuelas, las sectas, que se limitan y definen recíprocamente. Así como en política encontramos siempre a un partido liberal y a otro conservador opuestos entre sí, lo mismo ocurre en las actividades económicas — donde es más pronunciada la individualización de intereses-cuando el vendedor y el comprador están implicados en la misma relación recíproca. En cada caso, cada parte presupone la parte contraria, y ninguna de ellas podría ser exactamente lo que es sin la otra ${ }^{60}$. En las sectas, el papel de esta oposición al otro, como momento de fuerza en la formación del grupo, es menos claro. No puede afirmarse directamente que la existencia de una secta dependa de la existencia de otra. Aunque, desde luego, una secta solamente toma conciencia de su propia posición singular en la colectividad por medio de su oposición a otras o, incluso, a todos los hombres en general. Su propia significación y su carácter se alteran enseguida cuando tal oposición deja de existir. En general ocurre lo mismo con los grupos que con los individuos: solamente consiguen la autoconciencia mediante la oposición a otros grupos. Las representaciones que se hacen de si mismos están siempre entrelazadas con representaciones de otros grupos ${ }^{61}$.

Esta interacción singular, en la que incurren tanto los grupos como los individuos, la han estudiado diferentes autores, convirtiéndola en objeto de investigación científica, y lo han hecho desde los diversos puntos de vista de que partían. Tarde dedicó todo un ensayo a definir el concepto, e intentó reducir este tipo de interacción social, como antes había hecho con la imita-

${ }^{60}$ Bluntschl, Charakter und Geist der politischen Parteien, p. 3. «Los partidos son la manifestación y expresión naturalmente necesarias de los impulsos internos que mueven la vida política de la nación. El partido es, ciertamente, como ya lo indica la palabra pars, sólo una parte de un todo más amplio, nunca el mismo todo» (...) «no puede existir un partido por sí solo; únicamente la presencia frente a él del partido opuesto hace posible su existencia y su desarrollo.»

${ }^{61}$ ROYCE, Studies of Good and Evil, cap. VII, «Anomalies of Self-Consciousnes», p. 196. «Las funciones autoconscientes son todas ellas, en su aspecto finito, humano y primario, funciones sociales, que se deben a los hábitos de relaciones humanas. Implican la presentación de algún contraste entre el Ego y el no-Ego.» 
ción, a la forma de un proceso cósmico universal (contre-répétition). Afirmó que la oposición es, sencillamente, un tipo especial de imitación ${ }^{62}$.

Baldwin y Royce, por el contrario, consideraron la imitación y la oposición —en otras palabras, el impulso de auto-afirmación- como procesos paralelos que están activos siempre que hay gente reunida ${ }^{63}$. La actividad recíproca de estos dos procesos (de particularización y de generalización) la utilizó Baldwin como punto de partida para intentar explicar el desarrollo de los individuos auto-conscientes y también el de las formas sociales que los vinculan en una unidad $^{64}$.

Simmel presenta con mucha originalidad el proceso de diferenciación social y las diversas formas que adopta la oposición social en una serie de obras cuajadas de multitud de sutiles e interesantes observaciones ${ }^{65}$. Contempla la diferenciación social sociológicamente, es decir desde el ángulo de la colectivi-

${ }_{62}$ TARDE, L'opposition universelle, p. 10. «Me refiero a esa inclinación a pensar que uno es original porque ha defendido lo contrario a la opinión común o al ejemplo común. Todavía hay aquí una manera de imitar, y no es precisamente la menos extendida en las sociedades orgullosas, donde la gente se ufana de no copiar a su padre, a su vecino, a su superior, ni siquiera en aquello en lo que son mejores; allí donde, aun negando uno precisamente lo que otro afirma, condenando lo que el otro alaba, demoliendo precisamente lo que él construye, uno se convence a sí mismo de que no copia». Confróntese también TARDE, Les lois de l'imitation, Prefacio, 2. a ed., p. 11. «Hay, en efecto, dos medios de imitación: hacer exactamente lo que hace su modelo, o hacer exactamente lo contrario.» (Nota de los trads.: la expresión francesa en el texto principal es de Park).

${ }^{63}$ BALDWIN, en Social and Ethical Interpretations, p. 242, menciona este texto de una carta escrita por Royce: «Pienso que hay aquí un factor muy general desatendido que merece más estudio. Una gran región del funcionamiento social consiste en producir deliberadamente lo que he llamado 'efectos del contraste social'. Los cuestionamientos, la crítica, la obstinación social, el comadreo acerca del vecino, las réplicas de la oposición, el juego social de los sexos, en todas sus formas deliberadas..., todo esto son funciones cuyo propósito consciente no es reducir la unidad, ni disminuir las diversidades, sino encontrar, desvelar e insistir en las diferencias entre los sí mismos. Tales funciones constituyen casi la mitad de la vida social consciente. Oscurecen los elementos imitativos que realmente son tan universales, de tal forma que, al menos para la mayoria de la gente, el descubrimiento de la universalidad de la imitación surge como una sorpresa, como la sorpresa de saber que uno ha estado siempre hablando en prosa. Pues bien, como advierto, una buena parte de la inventiva de un individuo es una función debida a la aparición de efectos del contraste social, iluminándose mis contenidos conscientes con algún nuevo contraste con las ideas del otro;. Veo en mí mismo lo que nunca había visto antes y, entonces, tengo una "nueva idea". Uno de los propósitos grandes, psicológicamente potentes, de la vida social es el propósito de encontrarse uno mismo diferente de otro sí mismo. El propósito es vano con frecuencia, y sus expresiones conscientes están llenas de ilusiones divertidas para el espectador, pero de todos los grados de organización social, desde los niños en la plaza del mercado, hasta las naciones manteniéndose tercamente separadas entre sí, parloteando de glorias y elevando las tarifas aduaneras, uno podría afirmar, con una fuerza casi igual que la de la definición de Tarde, esto: que la sociedad es un despliegue recíproco de contrastes mentales.»

${ }_{64}$ BALDWIN, Social and Ethical Interpretations, libro II, "Society», pp. 459 y ss.

${ }_{65}$ Simmel, "Ueber soziale Differenzierung», Schmollers Staats-und Sozialwissenschaftliche Forschungen, vol. X, 1890; Simmel, Philosophie des Geldes, cap. IV, "Die individuelle Freiheit", pp. 279 y ss.; SimmeL, American Journal of Sociology, IX: 4. 
dad, y por eso discrepa de Royce y de Baldwin, quienes la abordan desde el ángulo psicológico e individual ${ }^{66}$. En general, se trata siempre del mismo proceso: el llamado «contra-imitación» por Tarde, «oposición» por Baldwin y Royce, y «diferenciación social» por Simmel.

Para caracterizar y describir ahora con mayor precisión el proceso sociológico denominado de «oposición», podemos considerarlo una forma especial de competencia. Se trata, en este caso, de un concepto tomado de la biología, mientras que la oposición, tal como la definen Baldwin y Royce, es, en primera instancia, un término psicológico. Si consideramos la oposición desde la perspectiva del grupo en lugar de hacerlo desde la del individuo, su conexión con el término competencia salta enseguida a la vista. Aquello que se presenta en la conciencia individual como un impulso de auto-afirmación, desde la perspectiva de la sociedad —en la que aquellos impulsos chocan entre sí- se manifiesta como una forma especial de la lucha universal por la existencia.

Lo que distingue el proceso sociológico del biológico son los ámbitos donde se producen. El biológico se da en el ámbito de la vida física. Las fuerzas que chocan entre sí son fuerzas físicas que se excluyen recíprocamente, como en el caso de una especie biológica que extermina a otra o la expulsa del área donde vive. El proceso sociológico, en cambio, tiene lugar en la conciencia de los individuos participantes y, en él, los intereses e ideales individuales se determinan recíprocamente y se adaptan entre $s^{167}$. Así ocurre en la guerra, a la que hay que considerar como una forma cruda de competencia social, y que no tiene como meta tanto la aniquilación como la coerción del oponente. Lo que lleva a un pueblo a probar su poder en la guerra contra otros no es sólo el afán de lucro, sino también el impulso de dominación. Vemos así, bastante a menudo, que el impulso de auto-afirmación que, con frecuencia, conduce a conflictos entre individuos y entre pueblos, queda satisfecho tan pronto como el sentido del honor o el prestigio de una de las partes queda a salvo y asegurado por la derrota y humillación del oponente. El vencedor no reclama la destrucción de su oponente; se contenta con el reconocimiento simbólico de su propia superioridad y su dominio sobre otro, además de otras satisfacciones más materiales. Puede hacerse una observación similar cuando dos ejércitos enemigos se preparan para la batalla. La mera presencia y el comportamiento de una

${ }^{66}$ BALDWIN, Social and Ethical Interpretations, p. 531. «Está claro que en el estudio del proceso social, podemos adoptar el punto de vista de la psicología social: el de la cuestión de por qué procesos mentales los hombres son realmente sociales y muestran una organización social. Pero también es posible adoptar el punto de vista de la sociología: el de la cuestión de qué encuentra un observador como yo cuando se introduce entre seres humanos que están organizados socialmente.»

Confróntese también C. Bouglé, Les idées égalitaires.

${ }^{67}$ FOUILLÉE, La psychologie des idées-forces, II:18. «Una vez formada, la imagen de los otros llega a ser una idea-fuerza o, más bien, una colección de ideas-fuerza siempre presentes en nuestra conciencia, con las cuáles contamos siempre y que manifiestan su influencia en todas nuestras acciones, en todos nuestros movimientos.» 
parte influye poderosamente sobre la otra, demostrando una vez más que no estamos sólo ante fuerzas físicas, sino también ante fuerzas ideales ${ }^{68}$. También se puede dar una explicación socio-psicológica semejante en el caso de que la victoria de un ejército produzca una nueva constelación de fuerzas ideales. De ahí la gran importancia que tienen los símbolos ofrecidos por una facción para indicar que se rinde a la otra. Mediante las ceremonias - entregar la espada o cualquier otra cosa-, ambas partes reconocen el cambio de situación y éste se proclama a todo el mundo ${ }^{69}$.

Desde el punto de vista psicológico, los procesos que se producen en la conciencia del vencedor y del vencido son totalmente distintos, pero, considerados ambos, parecen sencillamente momentos de un único proceso sociológico.

Es precisamente característico del proceso socio-psicológico tal como se entiende aquí que el proceso de conciencia de un miembro del grupo esté siempre vinculado a los correspondientes procesos de conciencia de los otros miembros. Sólo entonces esos procesos psicológicos individuales, que por sí mismos son diversos, pueden adquirir la significación de un proceso colectivo; porque, realmente, sólo pueden explicarse en un sentido socio-psicológico aquellos fenómenos que puedan ser remitidos a una conciencia colectiva ${ }^{70}$.

Esto resultará importante cuando se examinen de nuevo las características del público. Las diferencias mencionadas anteriormente entre masa y público -en concreto, la represión de los impulsos e intereses individuales en la masa, opuesta a la emergencia de éstos que se produce en el público- no impiden que vayamos a ver como un proceso colectivo lo que sucede en el público ${ }^{71}$. De

${ }^{68}$ FOUILLÉE, La psychologie des idées-forces, vol. I, Introducción.

${ }^{69}$ Confróntese Spencer, Sociology, vol. II, cap. VI, «Obeisances», donde se describen las diversas formas de sumisión y se presenta su desarrollo desde las formas primitivas de la expresión emocional.

${ }^{70}$ Münsterberg, Grundzüge der Psychologie, p. 558. «El contenido de la conciencia social está coordinado con el organismo social igual que el contenido de la conciencia individual con el cerebro particular. Así, el cerebro individual se incorpora a la relación como una neurona social cuyos procesos protoplásmicos existen en el sistema de los órganos sensoriales y cuya ruta de descarga está representada por todo el aparato motor externo. Incluso las neuronas unicelulares del cerebro individual no están fundidas, sino que están simplemente situadas juntas, de modo que una influye sobre la otra. Precisamente de esta manera, las neuronas sociales se influyen entre sí y, a partir de la conjugación de sus coordinaciones y oposiciones, se desarrolla la vida psicofísica de la colectividad. La psicología especial debe ascender de los elementos a las ideas y a las actitudes, y construir la personalidad partiendo de la relación entre ellos. Entonces, así como la psicología individual se inicia con la diversidad de los elementos, el estudio de la psicología social se prepara con las diversidades de las personalidades, y desde ahí, concibe las configuraciones de la vida social sistemática y sintéticamente emergiendo de la interacción de las personalidades.»

${ }^{71}$ (Nota de los trads.: la referencia de la nota faltaba en el texto). MÜNSTERBERG, Grundzüge der Psychologie, p. 134. "Por consiguiente, en el dominio de la psicología social, es posible distinguir de nuevo entre procesos como la política, la ciencia, el arte, el derecho, la religión, que suponen acciones individuales planificadas, y aquellos como el lenguaje, el mito, el hábito ético, que proceden de los impulsos de la masa. El estudio de los últimos puede delimitarse, otra vez, como psicología de los pueblos, aunque esta diferenciación es, en principio, secundaria.» 
hecho, este proceso se manifiesta simplemente como una modificación del proceso de imitación ya observado en la masa. Y esto es así porque la oposición social supone que oponentes como el comprador y el vendedor, el conservador y el liberal, etc., se sitúan recíprocamente en la posición de la conciencia del contrario y reproducen mutuamente sus sentimientos y su conducta ${ }^{72}$. Todos los sentimientos que Jodl calificaba como sentimientos hacia la propia persona dan por supuesta la existencia de la oposición social, porque sólo si nos encontramos en oposición a otros hombres somos capaces de sentir orgullo, piedad, alegría ante la desgracia ajena, etc. ${ }^{73}$.

Por lo tanto, la oposición social es un proceso que puede ser considerado desde dos perspectivas. Desde el punto de vista psicológico aparece como un proceso por el que individuo alcanza la auto-conciencia; en cambio, desde el punto de vista sociológico o socio-psicológico la oposición social es un proceso que pone a los individuos en relaciones recíprocas y que tiene un carácter más o menos permanente, sistemático. Un ejemplo de tal dependencia se ve en las relaciones entre el gobernante y el súbdito, el maestro y el discípulo, etc. Desde luego, todas éstas son determinaciones subjetivas, pero han adoptado una cierta validez objetiva al asentarse en la tradición y al ser objeto de reconocimiento general. Por eso, puede decirse que el individuo se conoce a sí mismo y conoce su posición en la colectividad (1) imitando a sus semejantes y (2) compitiendo con ellos ${ }^{74}$.

Allí donde esa relación de oposición social ha adoptado una forma permanente y más o menos sistemática, se desarrollan enseguida ciertos fenómenos propiamente socio-psicológicos de muy especial interés para este trabajo. Un ejemplo de esos fenómenos es el precio de las mercancías en el mercado. El comprador y el vendedor tienen intereses completamente distintos en las mercancías: uno quiere obtenerlas, el otro deshacerse de ellas. El precio puede entenderse como el producto que resulta de la interacción de ambos intereses opuestos; no se determina sólo por la valoración subjetiva del comprador ni por la del vendedor, tampoco por el valor objetivo o absoluto del objeto; sino a

72 BALDWIN, Social and Ethical Interpretations, p. 15. «Si fuera cierto, como vienen a demostrar muchas pruebas, que lo que la persona piensa de sí misma es un sólo polo o término situado en uno de los extremos del sentido global de la personalidad, y que el otro polo o término es el pensamiento que esa persona tiene de otra, del 'alter', entonces, es imposible aislar en momento alguno este pensamiento de sí mismo y decir que, al pensar en uno mismo, no se está esencialmente pensando también en alter.»

BALDWIn, Mental Development in the Child and the Race, p. 335. "Por tanto, el Ego y el alter han nacido juntos" (...) "Mi sentido de mí mismo se desarrolla al imitarte, y mi sentido de ti se desarrolla con arreglo a mi sentido de mí mismo. Ego y alter son, por tanto, esencialmente sociales: cada uno es socio e imitación creativa.»

${ }^{73}$ JodL, Psychologie, II:386. «En esta etapa del primitivo desarrollo de la conciencia, la voluntad sólo se determina a través de los sentimientos inmediatos y presentes, con los que se asocia una idea de su causa, que es el resultado de la experiencia previa. En la etapa del desarrollo secundario de la conciencia, el proceso de pensamiento se integra complementariamente con las impresiones inmediatas."

Confróntese STOUT, A Manual of Psychology, pp. 580 y ss.

${ }^{74}$ Cooley, «Personal Competition», Economic Studies, vol. IV (2 abril 1899): 78, 149. 
través de la interacción entre los distintos puntos de vista individuales y entre los intereses opuestos.

Un producto de la oposición social semejante al anterior es lo que llamamos prestigio. El prestigio procede del reconocimiento de una acción notable. Luego, por asociación, se vincula a los objetos e individuos que sólo se relacionan secundariamente con el hecho reconocido, como sucede cuando el prestigio del padre pasa al hijo e incluso a otros parientes que llevan el mismo nombre. Esto demuestra que lo que es en sí mismo un constructo subjetivo, cuando llega a concretarse en algo objetivo, obtiene una significación objetiva, y luego pasa a operar como una fuerza natural en la sociedad. Donde mejor se ve esto es en el fenómeno de las epidemias sociales ${ }^{75}$.

En la opinión pública tenemos también, finalmente, un fenómeno sociopsicológico que resulta del comportamiento crítico de varios individuos o grupos enfrentados. Hay que añadir, de todos modos, que lo que ordinariamente llamamos público es un tipo de grupo que, en gran medida, se mantiene en el mismo nivel de desarrollo de la conciencia que la masa. Por consiguiente, la llamada opinión pública generalmente no es más que un impulso colectivo carente de ilustración que puede manipularse con eslóganes. El periodismo moderno, del que se supone que instruye y dirige la opinión pública al informar y discutir sobre los acontecimientos, tiende a convertirse sencillamente en un mecanismo para el dominio de la atención social. La "opinión» que surge de esta manera adopta una figura lógicamente similar al juicio derivado de la percepción irreflexiva: la opinión se forma directamente al percibir la idea.

Es característico de la masa que se mueva siempre en la etapa perceptiva del desarrollo de la conciencia ${ }^{76}$. En cambio, lo característico del público es que su conducta, que se expresa en la opinión pública, sea el resultado de una discusión en la que los individuos adoptan posiciones opuestas. Tal discusión se basa en el relato de los hechos ${ }^{77}$.

"Hecho» es, sin embargo, una noción nueva para nosotros. Aunque no se considere aquí el significado lógico de esta palabra, hay que clarificar, al menos, su significado socio-psicológico.

Hemos investigado ya el método de comunicación recíproca que se da, por ejemplo, entre los animales sociales. La reacción inconsciente de un animal hacia un objeto que divisa sirve como señal y sugestión para las reacciones de los otros animales. Esto supone que el objeto significa lo mismo para todos los miembros del grupo, pues, de otra manera, sería imposible explicar cómo se produce la comunicación.

75 Confróntese Spencer, Sociology, vol. I, cap. XX, p. 280, donde Spencer presenta el desarrollo del culto a los antepasados.

${ }^{76}$ SIDIS, Psychologie of Suggestion, p. 296.

${ }_{77}$ Del mismo modo que en los individuos la reflexión "presupone la existencia del pensamiento inconsciente», también hay que suponer que, cuando el grupo social pasa a la deliberación y al diálogo, existen ciertos hechos conocidos por todos a los que la discusión puede remitirse. Confróntese Windelband, Präludien, «Denken und Nachdenken». 
Cuando existen grupos como el público, donde los objetos tienen significados distintos para los diversos individuos, es necesario un nuevo método de comunicación, consistente en dividir el objeto, el acontecimiento, o lo que fuere, en sus elementos. Estos elementos, a su vez, pueden ser objetos, acontecimientos o elementos de la percepción, pero deben tener el mismo significado para todos los miembros del grupo. También esos elementos pueden, a su vez, ser objetos, acontecimientos o elementos perceptivos, pero deben, en todo caso, tener el mismo significado para todos los miembros del grupo. Entonces pueden ser considerados como «hechos».

Cuando se utiliza este método de comunicación es posible definir y describir los objetos y acontecimientos que tienen valores y significados diferentes para los diversos individuos del grupo haciéndolos así accesibles a todos ${ }^{78}$. Cuando vamos a comprar puros al estanco tendremos que poder constatar que los cigarros que nos ofrecen son de olor suave, de aroma agradable y cuestan veinticinco centavos. Hasta ahí los puros son lo mismo para el comprador y para el vendedor. Sin embargo, tendrán significados completamente distintos para cada uno, pues el vendedor quiere deshacerse de ellos y el comprador quiere fumarlos. El cigarro real tiene ahora significados distintos para los individuos distintos y tendremos que considerar el cigarro que tiene el mismo significado para todos como una construcción ideal ${ }^{79}$.

El público se desenvuelve en un mundo de objetos de ese tipo, que son producto de una construcción ideal y que tienen para todos el mismo valor objetivo aun cuando para los distintos individuos tengan distinto significado. Es característico de la naturaleza del público que exista una separación entre los puntos de vista subjetivo y objetivo desde donde se pueden contemplar los objetos del mundo. Aunque estos objetos sean definibles e inteligibles de igual modo por todos los diversos individuos, tienen valores diferentes para ellos. A través del proceso que se produce en el público, los diversos pareceres individuales entran en conflicto y se clarifican recíprocamente. Esto da lugar a la adopción de un criterio adecuado para el grupo en conjunto. Solamente si el propio grupo se considera como un sujeto que toma partido y actúa como una unidad, puede ser objeto de una explicación socio-psicológica ${ }^{80}$.

78 MÜnsterberg, Grundzüge der Psychologie, pp. 298 y ss.

79 STоuт, A Manual of Psychology, p. 313. «El mundo externo como construcción ideal es un producto social, por tanto, debe ser independiente del sujeto individual del mismo modo y en el mismo grado en que la organización social, en general, es independiente de sus miembros individuales. Se ha introducido así un nuevo factor en la constitución de la realidad externa: el factor social». Confróntese RoyCE, Studies of Good and Evil, "Selfconsciousness, Social Consciousness and Nature», pp. 198 y ss.

${ }^{80}$ Münsterberg, Grundzüge der Psychologie, pp. 99-100. «También el grupo humano se manifestará como portador del acontecer espiritual. El conocimiento y la voluntad de la comunidad nacional, económica, religiosa o de parentesco, no son menos reales que las funciones anímicas del hombre singular» (...) «Cuando en la realidad histórica se siente la dependencia del sentimiento y juicio sociales, y cuando se tiene en cuenta la postura del alma de un pueblo, la realidad de ese sujeto social con que topamos no se percibe en absoluto como tal sujeto real, como si 
No hay que caer en el error de considerar la opinión pública como una opinión que incumbe por igual a cada miembro del público. Se trata, más bien, de una opinión o de un comportamiento que se presenta como ajeno frente a cada individuo y que se considera objetivo. Precisamente porque hay que concebirla como el producto de las actitudes críticas individuales, la opinión pública se expresa de modo diverso en los distintos individuos.

Pero no se trata sólo de eso. Se han encontrado otros productos de esta conducta crítica como, por ejemplo, el prestigio y los precios de los bienes de consumo. Caracteriza aún mejor al público el que en él los diferentes puntos de vista de los diversos individuos se consideren subjetivos. El reconocimiento de los puntos de vista de los diversos individuos, que se alcanzó históricamente, por primera vez, en la ilustración griega, caracteriza al público, distinguiéndolo de otros tipos de grupo, como la masa o la secta ${ }^{81}$. Con el reconocimiento del valor y relevancia de los puntos de vista subjetivos, surgió, por primera vez, el anhelo de interpretar y explicar la experiencia individual desde una perspectiva supra-individual, es decir, normativa ${ }^{82}$.

Ya hemos visto que esta perspectiva supra-individual se reconoce con el surgimiento del público, cuando la discusión — que es el único camino para que se desarrolle la opinión pública- se basa en los hechos. Los hechos son elementos de la realidad concreta que tienen el mismo valor para todos los hombres, o al menos, para todos los miembros de un grupo. Si en el lugar de la realidad concreta ponemos esos hechos, tenemos un objeto ideal construido con valor uniforme para todos los miembros del grupo. La realidad concreta con que ese objeto se relaciona tiene, sin embargo, un significado distinto para cada miembro del grupo.

Advertimos, ciertamente, que los objetos y los acontecimientos del mundo

fuera un simple complejo de individuos particulares. Tampoco en la vida cotidiana las personas son percibidas como un complejo de células. Si los motivos para el reconocimiento del sujeto social se transfieren al lenguaje de la psicología, seguramente, se hace necesario comenzar percibiendo muchos sujetos individuales. Cada descripción retorna a aquellas células del cuerpo social, pero, en lo que respecta a mi dependencia real y a mis ocupaciones reales, el todo sólo es válido como todo. El sujeto individual real, por consiguiente, no está contenido como parte en el sujeto real social, sino que ambos se interpenetran como realidades diferentes por antonomasia, y, sólo cuando se piensan como objetos existentes, se convierte uno en elemento del otro».

${ }^{81}$ Windelband, Präludien, «Ueber Socrates», 1.a ed., p. 61. "Por primera vez en la historia nos encontramos aquí con un pueblo cuya circunstancia vital estuvo toda ella influida por la formación espiritual, un pueblo que colocó la dirección de los asuntos públicos en manos de espíritus superiores, un pueblo, en suma, que elevó la formación a elemento esencial de su ser nacional» (...) «Al mismo tiempo que esta formación se filtraba en el cuerpo de la población ateniense, las raíces con las que el individuo había crecido en la tierra de la conciencia general se debilitaron, y éste aprendió a seguir su propio juicio. Esta es la estirpe de la que podría decirse que descubrió la libertad; la libertad del individuo que quiere observar y pensar por sí mismo, que rechaza la autoridad, que descompone su cielo en átomos, que se define a sí mismo como medida de todas las cosas, y se proyecta como átomo autodeterminado de un mundo.»

82 Windelband, Geschichte der Philosophie, p. 54. "La cuestión de si hay algo de validez general es el problema del período antropológico de la filosofía griega o de la ilustración griega.» 
exterior tienen siempre diversos sentidos para los distintos hombres al llegar a ser auto-conscientes, pues "auto-consciente», en el sentido en que lo utilizamos aquí, significa la distinción de uno mismo como individuo que siente y quiere de otros individuos que sienten y quieren ${ }^{83}$. Sin embargo, en el momento en que divergen los intereses y puntos de vista individuales, la vida práctica requiere una definición y una interpretación de los objetos y acontecimientos del mundo exterior que sea aceptable para todos. Por esto surge la necesidad de una interpretación puramente teórica de las cosas que esté libre de valores individuales.

Se ve así como en el público se separan la conducta práctica y la teórica del grupo. No se trata de que el «momento práctico» esté totalmente ausente en la actitud teorética, pues, así como fueron precisamente motivos ético-políticos la fuente de los primeros intentos de establecer un conocimiento que pudiera reclamar una validez general sobre la diversidad de opiniones ${ }^{84}$, el momento práctico se hace valer siempre en las ciencias. Y de tal modo, que las respuestas que las ciencias dan a sus problemas están predeterminadas no sólo por el material disponible, sino, también de antemano, por el modo de plantear las preguntas ${ }^{85}$.

Es ciertamente distintivo del público que su comportamiento sea doble. El «ser» de las cosas —aquel significado que aceptan como idéntico todos los miembros del grupo-, y su "valor» — que es distinto para todos los miembros-, divergen al nacer un público, mientras que, en la masa, el «ser» y el «valor» coinciden. Al intentar fundamentar su conducta práctica sobre consideraciones teóricas, y al determinar su voluntad a través de la deliberación y de la discusión, el público se somete de nuevo a las normas teóricas. Estos son los presupuestos necesarios para la existencia del público porque "el hombre puramente abstracto puede existir más allá del bien y del mal, pero nunca más allá de lo verdadero y de lo falso" ${ }^{86}$.

Una vez aceptadas, las normas abstractas operan como una nueva fuerza en la vida colectiva.Y es, precisamente, esta nueva fuerza la que está activa en el público, y no así en la masa ${ }^{87}$.

${ }^{83}$ RoyCE, Studies of Good and Evil, «Consciousness and Nature», p. 215. «Mi opinión significa, en general, mi opinión contrastada con opiniones que atribuyo a otros hombres. Mi experiencia privada significa, primeramente, aquello que nadie, salvo yo, ha experimentado y, por consiguiente, se define por contraste con la concepción de lo que cualquier otro ha experimentado.» (... ) «Quitemos toda esta otra experiencia de mi concepción e, inmediatamente, pierdo todos los medios para llegar a ser consciente de mi experiencia como propia, o de conocer lo que entiendo como individualidad global o como mi Ego presente.» Confróntese FICHTE, Grundlage des Naturrechts, Sämtliche Werke. 2. ${ }^{\text {a }}$ parte, vol. 1, p. 8.

84 Windelband, Geschichte der Philosophie, p. 74.

${ }^{85}$ Confróntese Rickert, Der Gegenstand der Erkenntnis; Windelband, Präludien, p. 29.

${ }^{86}$ RICKERT, Der Gegenstand der Erkenntnis, p. 90.

87 Windelband, Präludien, "Normen und Naturgesetze», p. 271. «Si ocurre que la conciencia de las normas - aún cuando no aumenta empíricamente la vitalidad ni el poder de autopreservación de su portador - no sólo se mantiene en la historia del ser humano sino que se intensi- 
El público intenta determinar su voluntad mediante la deliberación y la discusión. Trata de evaluar y determinar las definiciones individuales de valor desde una perspectiva supra-individual. Sin embargo, también es característico del público que nunca alcance ese punto de vista. Lo que falta es el reconocimiento de normas prácticas, la aceptación del derecho ${ }^{88}$. La opinión pública no la aceptan los miembros del grupo como una norma. Los individuos que se influyen mutuamente en el público no lo hacen como seres libres recíprocamente investidos de autoridad. El público no es un grupo legislador. La opinión a través de la cual el público domina a sus miembros individuales es un producto puramente psicológico, sin ninguna validez normativa. A diferencia de la opinión pública, las leyes no pueden considerarse como productos psicológicos porque también son válidas cuando dejan de operar como fuerzas naturales en la conciencia colectiva ${ }^{89}$.

Tal vez pueda explicarse psicológicamente el desarrollo de estas normas, pero de esa manera no se fundamenta su validez ${ }^{90}$. La opinión pública nos presenta sólo una parte de las cambiantes circunstancias psicofísicas del grupo. Las leyes se fundamentan sobre una tradición firme, sobre una sustancia espiritual que nunca se puede equiparar con las cambiantes circunstancias del grupo. A esta sustancia espiritual del grupo se le denomina «la voluntad general».

fica, profundiza y refina en algunos aspectos, es necesario que tenga que basarse en una fuerza directa e independiente de todo efecto secundario que habita en la propia conciencia de las normas. Una fuerza que, una vez que entra en vigor, eleva la conciencia moral al rango de fuerza psicológica entrando así a formar parte, como un nuevo factor, en el movimiento de la vida anímica. Sólo entonces el hombre ha entendido la esencia verdadera y el significado psicológico de las normas.»

${ }^{88}$ FICHTE, Grundlage des Naturrechts, Sämtliche Werke, sec. 2, vol. I, p. 8. «El procedimiento de formulación del concepto de derecho cabe representarlo del siguiente modo: me supongo a mí mismo racional, es decir, libre. La idea de libertad está presente en mi en este asunto. Supongo, a la vez, otros seres libres en el mismo acto indiferenciado. Después de esto, y utilizando mi poder imaginativo, dibujo una esfera para la libertad que comparten varios seres. No me atribuyo toda la libertad que he dispuesto porque supongo la presencia de otros seres libres y debo asignarles una parte de ella. Me limito a mí mismo en mi adjudicación de la libertad por el hecho de que también dejo libertad para los demás. De acuerdo con ello, el concepto de derecho es el concepto de las necesarias relaciones recíprocas de los seres libres.»

${ }^{89}$ Hegel, Philosophie des Rechts, sec. 318. «La opinión pública merece, por consiguiente, ser tanto apreciada como despreciada; esto último respecto de su conciencia y exteriorización concreta, aquello por su fundamento esencial, que sólo se reflejará, de una manera más o menos turbia, en aquella concreción.» (Nota de los trads.: citamos por la versión castellana, levemente retocada, de Juan Luis Bernal, Principios de la Filosofía del Derecho, Buenos Aires: Sudamericana, 1975 , p. 365 .)

90 Windelband, Präludien, «Normen und Naturgesetze», p. 214. 


\section{CAPITULO III \\ LA VOLUNTAD GENERAL}

I

La noción de voluntad general apareció por primera vez en la filosofía moderna en la teoría de Rousseau de la "volonté de tous» ${ }^{1}$. Es cierto que Hobbes y Locke habían presentado ya ideas semejantes. Hobbes, por ejemplo, afirmaba que el estado era una "unidad real», y que debería ser considerado como una persona; pero «real» en este sentido sólo puede significar que el estado es el portador del poder unificado de los individuos que en él están conjuntamente vinculados, porque el estado se basa en el contrato, es un «hombre artificial» ${ }^{2}$. Del mismo modo debería entenderse por "persona» la persona jurídica, portadora de los derechos cedidos por los individuos ${ }^{3}$. Para Hobbes no existe una "persona moral» que reconozca en su propia conciencia el poder de una ley superior y, por ello, la voluntad general está tan lejos de identificarse con la voluntad "real» de los individuos que el estado sólo llega a existir cuando las voluntades individuales se someten a la voluntad del gobernante y se subordinan incondicionalmente a sus órdenes ${ }^{4}$.

Para el ser humano el estado de naturaleza es un estado de hostilidad recíproca, la bellum omniun contra omnes. Sólo cuando se logra superar este estado de naturaleza comienza a existir el estado. Cuando el mismo se erige, las voluntades individuales se someten a la voluntad de la colectividad, representada en la persona y voluntad del gobernante. Esta voluntad general se da siempre como algo ajeno a los individuos. Según Hobbes no existe el auto-gobierno ya que la norma es, siempre y necesariamente, una fuerza de dominación ${ }^{5}$.

Esta doctrina de la permanente posición de recíproca extrañeza entre el poder del estado y el individuo cuya libertad limita aparece repetidamente en otros autores, incluso en quienes no concuerdan con Hobbes, como Goodwin, John Stuart Mill y Spencer ${ }^{6}$. La doctrina recibió su formulación clásica en la afirmación de Bentham: "El estado es un mal necesario" (Government is a necessary evil) ${ }^{7}$. Es común a todos estos autores la suposición de que se da una completa disyunción entre el individuo y el estado. Sin embargo, esto no hay que entenderlo en el sentido hegeliano, según el cual el individuo sólo encuentra su verdadero yo y su libertad en el estado. Significa, no obstante, que el

${ }^{1}$ Bosanquet, The Philosophical Theory of the State, p. 13.

${ }^{2}$ Hobbes, Leviathan, 2. ${ }^{\text {a }}$ parte, cap. XVII, y prólogo. Cfr. también KISTIAKOWSKI, Gesellschaft und Einzelwesen, p. 10.

${ }^{3}$ Bosanquet, The Philosophical Theory of the State, p. 93.

${ }^{4}$ Bosanquet, The Philosophical Theory of the State, p. 104. Windelband, Geschichte der neueren Philosophie, vol. I:154.

5 Janet, Histoire de la Science Politique, vol. II, p. 182.

${ }_{6}^{6}$ Bonar, Philosophy and Political Economy, pp. 199 ss. Bosanquet, The Philosophical Theory of the State, pp. 60 y ss. y 69 y ss.

7 Bentham, Principles of Legislation, p. 48. (Nota de los trads.: el autor reproduce el aserto original de Bentham junto a su libre versión alemana). 
individuo debe renunciar siempre a una parte de su libertad en favor del estado, en la medida en que esto sea necesario para asegurar igual libertad para todos los demás individuos ${ }^{8}$.

Las obras de Rousseau representan la transición histórica de la doctrina de Hobbes y Locke a la de la voluntad general, tal como aparece en la filosofía política de Hegel ${ }^{9}$. Locke escribió su Essay on Civil Governement sobre todo para justificar la revolución inglesa ${ }^{10}$. Se separaba de la teoría de Hobbes al creer que la voluntad general se fundaba en último término en la comunidad y que era asumida sólo temporalmente por el rey y el gobierno para el ejercicio representativo del poder $^{11}$. La voluntad que de hecho se hace valer en la comunidad no es, por tanto, la voluntad de la colectividad, sino la del soberano que la ejerce en los términos de la constitución. Esta transferencia de soberanía al rey y al parlamento es siempre condicional y puede revocarse tan pronto como no se cumplan las estipulaciones ${ }^{12}$. Para Locke la voluntad general no era una voluntad real, sino que era solamente la toma de postura de los individuos - ya fuera de aprobación o de rechazo - frente a las acciones del gobierno: no consideraba a tales individuos como una colectividad, sino como personas separadas. "Por consiguiente, afirma Bosanquet, puede decirse que para Hobbes la unidad política se basa en una voluntad que es real pero no común (no es una voluntad general); es, concretamente, la voluntad del soberano. Para Locke, en cambio, esta unidad reside en una voluntad que, aunque es general, no es real $»^{13}$.

Rousseau empleó a menudo el lenguaje de Locke y de Hobbes; y, tomados globalmente, sus escritos parecen vacilar entre la adopción del concepto más temprano de unidad social, que sitúa dicha unidad por encima y fuera del círculo de las voliciones individuales, y la del concepto posterior, que la sitúa en una voluntad general consistente en una orientación real y substancial y no en el consentimiento colectivo ${ }^{14}$. La reincidencia en las doctrinas más antiguas se manifiesta con la mayor nitidez en el intento de Rousseau de formular el mecanismo social mediante el cual el estado debería determinar esa voluntad general. Este consiste para él en un régimen desenfrenado de mítines públicos que debería contener la indivisa soberanía del estado ${ }^{15}$.

${ }^{8}$ MiLl, On Liberty, cap. IV.

9 Bosanquet, The Philosophical Theory of the State, p. 13. "Porque es Rousseau quien se encuentra entre Hobbes y Locke por un lado y entre Kant y Hegel por otro...» (...) «y él legó a sus sucesores la tarea de sustituir por meras palabras y ficciones contractuales, la naturaleza y la libertad original, la idea de la vida común de un ser esencialmente social que expresa y sostiene la voluntad humana del mejor modo posible.»

${ }^{10}$ JANET, Histoire de la Science Politique, vol. II, p. 199.

${ }^{11}$ LOCKE, Essay on Civil Government, cap. VII.

12 LOCKE, Essay on Civil Government, caps. XIII y XVIII.

13 Bosanquet, The Philosophical Theory of the State, p. 104.

${ }_{14}$ Richtie, Natural Rights, p. 49.

15 Rousseau, Du contrat social, vol. III, cap. XV. «La soberanía no puede representarse, por la misma razón que no puede ser enajenada: consiste esencialmente en la voluntad general, y ésta 
Vemos así mismo que al presentar su doctrina Rousseau empleaba la ficción histórica del contrato social, pero concibió dicho "contrato" como una relación universal y constituyente, con cuyo reconocimiento comienza a existir el estado ${ }^{16}$. Incluso cuando este concepto del contrato social se formula con sus rasgos más generales, no significa nada más que el reconocimiento mutuo de los individuos como personas que tienen derechos y deberes. Y de este modo, el contrato social es la expresión formal de la conciencia normativa que constituye el requisito previo de las relaciones concretas entre los individuos dentro de la comunidad política ${ }^{17}$. Por otra parte, Rousseau considera el estado original del hombre anterior al establecimiento de los vínculos sociales con los otros como una situación de libertad natural. En sus primeras obras habla de la sociedad como si su nacimiento significara la supresión de la libertad del individuo ${ }^{18}$. En cambio, en El contrato social contrapone la libertad natural del individuo, libre de vínculos sociales, con la nueva libertad que el hombre obtiene dentro del estado ${ }^{19}$.

Las enseñanzas de Rousseau se oponen a las de Hegel, ya que éste consideraba que la llamada libertad natural, anterior al individuo moral, era exactamente lo contrario de la libertad ${ }^{20}$. La libertad, en el sentido en que la entiende

no puede ser representada» (...) «Toda ley no ratificada en persona por el pueblo es nula; no es una ley. El pueblo inglés piensa que es libre, pero se equivoca; sólo lo es durante la elección de los miembros del parlamento; una vez elegidos, se convierte en esclavo, no es nada.» (Nota de los trads.: citado por la versión castellana de María José VILLAVERDE, El contrato social, Madrid: Tecnos, 1988, p. 94.) Cfr. Richtie, Natural Rights, p. 50; Windelband, Geschichte der neueren Philosophie, p. 436.

${ }^{16}$ Rousseau, Du Contrat Social, vol. III, cap. XV. (Nota de los trads.: en realidad es el primer párrafo del capítulo VIII del vol. I.) «Este paso del estado de naturaleza al estado civil produce en el hombre un cambio muy notable, al sustituir en su conducta la justicia al instinto y al dar a sus acciones la moralidad que les faltaba antes. Es entonces solamente, cuando la voz del deber reemplaza al impulso psíquico, y el derecho al apetito, y el hombre, que hasta ese momento no se había preocupado más que de sí mismo, se ve obligado a actuar conforme a otros principios y a consultar a su razón en vez de seguir sus inclinaciones.» (Cfr. versión castellana, cit., p. 19.)

17 Windelband, «Was ist Philosophie», Präludien, p. 49. "La validez de la conciencia normativa como medida absoluta de los juicios lógicos, éticos y estéticos, se encuentra como supuesto indispensable en la base de todas las funciones superiores del hombre y, sobre todo, de aquéllas que, al ser producto de la cultura social, tienen como contenido la producción y preservación de aquello que se encuentra por encima del arbitrio individual.»

18 Rousseau, Discours sur l'Origine de l'Inegalité parmi les Hommes, 1. a parte. «Esto es lo que ocurre con el hombre; al convertirse en sociable y esclavo se hace débil, temeroso y servil.»

19 Rousseau, Du Contrat Social, libro I, cap. VIII. «Lo que pierde el hombre con el contrato social es su libertad natural y un derecho ilimitado a todo lo que le atrae y que puede alcanzar; lo que gana es la libertad civil y la propiedad de todo lo que posee»; (...) «en el haber del estado civil se podría añadir, a lo dicho anteriormente, la libertad moral, la única que convierte al hombre en verdadero dueño de sí mismo; porque el impulso exclusivo del apetito es esclavitud y la obediencia a la ley que uno se ha prescrito es libertad.» (Cfr. versión castellana, cit., pp. 19-20.) Cfr. Hegel, Philosophie des Rechts, parágrafo 258.

${ }^{20}$ Hegel, Philosophie des Rechts, parágrafo 194. 
Hegel, sólo la alcanza el individuo moral que aspira a un ideal racional; la libertad, por lo tanto, sólo se realiza en el estado ${ }^{21}$.

El acercamiento de Rousseau a Locke se muestra en que el elemento más importante de su enseñanza es la distinción entre la volonté générale (voluntad general) y la volonté de tous (voluntad de todos). El asentimiento general no debe interpretarse como una expresión de la voluntad general ${ }^{22}$. Lo que constituye el ser de la voluntad general no es la coincidencia casual de las voluntades empíricas de los individuos, sino que únicamente cabe hablar de una voluntad general cuando se quiere lo universal y cuando ese querer adopta la forma de una ley que es igualmente válida para todos y en todo tiempo: sólo cuando el individuo se somete a una ley general y no sigue sus impulsos momentáneos, la decisión resultante de la votación general coincide con la voluntad general ${ }^{23}$.

Pero es fácil concluir, a partir de eso, que la voluntad de los individuos es lo mismo que la voluntad general o, al menos, que hubiera que considerarla como aquella expresión subjetiva de la voluntad general que, según Hegel y como veremos enseguida, se produce de hecho. Sin embargo, para Rousseau esta interpretación era imposible, puesto que mantuvo la antigua separación entre el pueblo (peuple) y el gobierno (gouvernement). En consecuencia, no señaló en absoluto un órgano específico para determinar la voluntad general (volonté générale), como tampoco lo hizo Locke. El gobierno no es ese órgano, pues, de acuerdo con Locke, sólo tiene temporalmente la soberanía en sus manos, y, según Rousseau, es un mero órgano administrativo ${ }^{24}$. Para conseguir

${ }^{21}$ W. Wallace, «Person and Personality», Lectures and Essays, p. 266. «La personalidad, en una palabra, es una cualidad del ser humano que expresa su naturaleza moral. Y la naturaleza moral del hombre reside en estar subordinado a una ley general, o en ser miembro de una comunidad, de la que constituye una parte integrante y en la que desempeña una función. Por tanto, la personalidad, como la moralidad, sólo pertenece al ser humano en la medida en que, aún siendo un individuo psíquico, es implícitamente universal.»

${ }^{22}$ Rousseau, Du Contrat Social, libro II, cap. III. «Se sigue de todo lo que precede que la voluntad general es siempre recta y tiende siempre a la utilidad pública; pero no que las deliberaciones del pueblo alcancen siempre el bien, pues éste no se ve siempre. El pueblo jamás se corrompe, pero se le engaña con frecuencia, y sólo entonces es cuando parece querer lo que está mal.

Con frecuencia hay bastante diferencia entre la "voluntad de todos" y la "voluntad general"; ésta no mira más que al bien común, la otra atiende al interés privado, y no es más que una suma de voluntades particulares.» (Cfr. versión castellana, cit., p. 28; hemos modificado levemente la traducción para ajustarla mejor al original.)

${ }^{23}$ Rousseau, Du Contrat Social, libro II, cap. VI.

${ }^{24}$ LOCKe, Essay on Civil Government, cap. II, sec. 22. Bosanquet, The Philosophical Theory of the State, p. 105. "Locke piensa que el gobierno actual es un fideicomiso y que el poder supremo último permanece en la comunidad como un todo»... "Pero el fideicomiso es condicional y teóricamente revocable; el poder supremo último está en la comunidad en su conjunto, que puede retirar la confianza si se violan las condiciones. Desde luego, no se sugieren ni pueden sugerirse los medios para hacerlo de una manera legal y, por tanto, la voluntad del pueblo no la expresa Locke como una voluntad real o actual.» Cfr. Rousseau, Du Contrat Social, libro III, cap. I. (Nota de los trads.: las expresiones francesas que van entre paréntesis en el texto principal aparecen en el original.) 
determinar la voluntad general es necesario recurrir al consenso general de los ciudadanos ${ }^{25}$.

El concepto de la voluntad general, que sólo encontramos bosquejado en la doctrina de Rousseau, fue adoptado y desarrollado más tarde por la filosofía alemana clásica. Su figura más plena se encuentra en las ideas de Hegel sobre el espíritu objetivo ${ }^{26}$. Hegel reunía en este concepto los dos aspectos de la voluntad general —el moral y el legal — que la insistencia, en cierta medida unilateral, de Kant en la autonomía del individuo había puesto en oposición. La voluntad autónoma es aquella que se eleva por encima del sistema de impulsos empíricos y que se determina únicamente por la ley de la razón. La ley moral más alta dice así: obra como si la máxima de tu acción tuviera que convertirse por medio de tu voluntad en la ley general de la naturaleza ${ }^{27}$. Aunque esa ley es de necesidad general y válida para todos los hombres, resulta ser puramente formal, porque, como subrayó Hegel, sólo requiere el acuerdo formal del individuo consigo mismo ${ }^{28}$. El individuo se impone la norma que debe seguir. El subjetivismo de esta interpretación se revela en la doctrina de que sólo la buena voluntad es buena ${ }^{29}$. La filosofía del derecho de Kant no atribuye nin-

25 Bosanquet, The Philosophical Theory of the State, p. 116. "Ahora todo esto deja claro que al esforzarse por destacar la señal de la voluntad general, Rousseau está entronizando realmente la voluntad de todos» (...) «Al reducir los mecanismos para la expresión del bien común al juicio aislado y desasistido de los miembros del cuerpo global de los ciudadanos, Rousseau está asegurando exactamente lo contrario de aquello que declara pretender. En lugar de apelar a la vida organizada de las instituciones y a la capacidad selectiva de una nación, pasa a apelar a la nación contemplada como un agregado de individuos aislados. Y, por consiguiente, está entronizando como soberano, no a la mente nacional, sino a aquel agregado de intereses e ideas privados que él mismo ha descrito como la voluntad de todos.»

26 Windelband, Geschichte der neueren Philosophie, II:326 ss. "La doctrina de Hegel sobre el espíritu objetivo incluye en su sentido más amplio toda aquella área a la que se aplica hoy el insulso nombre de sociología»(...) «La esencia del espíritu objetivo sólo se completa cuando coinciden las formas exteriores e interiores. Hegel llamó eticidad (Sittlichkeit) a esta síntesis de legalidad y moralidad y la distinguió expresamente de la moralidad (Moralität).»

27 Windelband, Geschichte der neueren Philosophie, II:116.

${ }^{28}$ Hegel, Philosophie des Rechts, parágrafo 135. «Es sin duda esencial poner de relieve que la autodeterminación de la voluntad es la raíz del deber. Por su intermedio el conocimiento de la voluntad ha ganado en la filosofía kantiana por primera vez un fundamento y un punto de partida firmes con el pensamiento de su autonomía infinita. Pero, en la misma medida, el permanecer en el mero punto de vista moral sin pasar al concepto de la eticidad, convierte aquel mérito en un vacío formalismo y la ciencia moral en una retórica acerca del deber por el deber mismo. Desde este punto de vista no es posible ninguna doctrina inmanente del deber. Se puede aportar una materia dada del exterior y llegar así a deberes particulares; pero si se parte de la determinación del deber como falta de contradicción o concordancia formal consigo mismo, que no es otra cosa que el establecimiento de la indeterminación abstracta, no se puede pasar a la determinación de deberes particulares. Tampoco hay en ese principio ningún criterio que permita decidir si un contenido particular que se le presente al agente es o no un deber. Por el contrario, todo modo de proceder injusto e inmoral puede ser justificado de esta manera.» (Cfr, versión castellana cit., p. 166.)

29 Windelband, Geschichte der neueren Philosophie, II:326. «Hay que reconocer la profunda sabiduría de Hegel al atender a la ética desde un punto de vista objetivo, y no subjetivo. Precisa- 
gún valor moral inherente a las instituciones públicas: ésta es la divergencia más importante entre su filosofía del derecho y la de Hegel.

A los efectos de nuestra exposición es necesario tener en cuenta la importancia especial de la teoría del estado y del derecho de Fichte, pues ofrece la transición de la teoría del estado del siglo XVIII a la del XIX, es decir, el tránsito desde el concepto subjetivo de la norma ética de Kant a la interpretación objetiva de $\mathrm{Hegel}^{30}$. Para Fichte el deber del individuo consiste en una específica determinación de la voluntad supra-individual. "La voz de la conciencia, que muestra a cada uno su deber particular, es el timón con que salimos del infinito y nos establecemos como seres individuales y particulares; esta voz establece los límites de nuestra personalidad; es también nuestro elemento verdaderamente primitivo, la base y la materia prima de toda la vida que vivimos» ${ }^{31}$.

Este concepto de la vida supra-individual se había anticipado históricamente por primera vez en la idea kantiana de la "conciencia en general»" ${ }^{32}$ Y, aunque en él encontremos una ruptura total con la filosofía de la Ilustración, Fichte siguió la línea de Hobbes, por cuanto su estado comercial cerrado presentaba al estado simplemente como la suma de las condiciones externas bajo las cuales el individuo podría realizar su destino ${ }^{33}$. Sin embargo, ese concepto del estado experimentó un continuo desarrollo en las diversas formulaciones de su doctrina. Antes de la publicación de su ensayo sobre «el estado comercial cerrado", Fichte se había ufanado ya de haber sido el primero en concebir el estado como un organismo ${ }^{34}$. Aunque la idea estaba contenida ya en su teoría de la moral, cobró por primera vez una expresión clara en el Discurso a la nación alemana: el estado es también un individuo, con un destino determinado, en cuya realización consiste su verdadera vida ${ }^{35}$.

mente el subjetivismo de la filosofía moral de Kant y Fichte ha mostrado que el principio de la ética ha de buscarse por encima del individuo. La conciencia moral y la legislación moral nunca se derivan del "yo" individual. Se enraizan, por el contrario, en la relación mediante la cual el individuo se sabe subordinado a la razón general.»

30 Windelband, Fichtes Idee des deutschen Staates, p. 9. «Donde el siglo anterior racionalizó, quiere el nuestro nacionalizar. En medio se encuentra Fichte, un Jano bifronte, que deja que suene la llamada hacia el futuro, pero que está aún lleno de las ideas del pasado.»

${ }^{31}$ FiCHTE, Die Bestimmung des Menschen, p. 299.

32 Windelband, Geschichte der Philosophie, pp. 445 y 448.

33 Windelband, Geschichte der neueren Philosophie, II:222. "Cuando (Fichte) publicó su Grundlage des Naturrechts (1796) estaba todavía completamente en la concepción externa del siglo XVIII. A partir del principio de doctrina científica, dedujo la pluralidad de las personalidades corpóreamente organizadas y descubrió que, en aquella externa vida en común, la libertad de cada individuo tenía que ser limitada por la de los otros. Pero cuando consideraba al Estado como medio para lograrlo vinculó sus funciones sólamente a la conexión externa, y no a los fines morales.»

${ }^{34}$ Fichte, Grundlage des Naturrechts, p. 209. Cfr. Wallace, «The Relations of Fichte and Hegel to Socialism", Lectures and Essays, p. 427.

35 Fichte, Reden an die deutsche Nation, p. 381. "Si se parte desde la perspectiva de un mundo espiritual, concibiéndola en su significación más alta y plena, un pueblo es esto: la totalidad de los hombres que en mutua sociedad se sobreviven y se reproducen de continuo, tanto física como espiritualmente; y que están conjuntamente sometidos a una ley particular del desarro- 
Se ha señalado ya que en la doctrina de Hegel sobre el espíritu objetivo alcanza su figura más completa el concepto de voluntad general procedente de Rousseau. En su Filosofía del Derecho, Hegel definió el estado en el mismo sentido en que lo hizo Fichte en su Discurso a la nación alemana: un individuo espiritual cuya esencia es una determinación particular del espíritu general que se realiza en la historia universal ${ }^{36}$. Por tanto, el estado no es una obra de arte ni un mero ideal que flota sobre los individuos de la sociedad; es algo real, una sustancia espiritual que se ha realizado en sus propias instituciones ${ }^{37}$.

Así como la verdadera esencia del individuo, su voluntad real, nunca coincide con la voluntad empírica —en la que sólo se expresa fragmentariamente-, ocurre también que «el espíritu del pueblo no habla en el intercambio de las opiniones del momento, ni en en el arbitrio del portavoz parlamentario, sino en la compacta estructura que el edificio del estado obtiene en su continuo desarrollo ${ }^{38}$. En Hegel la substancia ética, a la que llamó eticidad (Sittlichkeit) y que identificamos aquí con la volonté générale de Rousseau, adopta tres formas diferentes. En la familia encontramos la voluntad general en su forma inmediata, la del sentimiento y el impulso natural ${ }^{39}$. La familia es la forma natural de la sociedad por cuanto está también contenida en el estado ${ }^{40}$. La unidad aquí advertida es inmediata; en ella, los elementos individuales no gozan de independencia alguna frente a la colectividad. "El derecho que corresponde al individuo en virtud de la unidad familiar y que, en un primer momento, constituye su vida dentro de esta unidad sólo alcanza la forma jurídica como forma del momento abstracto de la individualidad determinada cuando la familia entra en disolución. Los que debían ser miembros devienen entonces, en su disposición y en la realidad, personas independientes, y, por consiguiente, lo que ellos constituían en la familia como momento determinado lo mantienen, ahora, en la separación, sólo en sus aspectos exteriores: los bienes, la alimentación, los costos de educación, etcétera» ${ }^{41}$.

Si la familia se descompone en sus elementos individuales, de modo que, al separarse, los miembros sólo se relacionen con vínculos externos, tendremos la

llo divino. Lo común en esta ley particular consiste en que vincula - tanto en el mundo eterno como también, por consiguiente, en el temporal - a dicha multitud en una totalidad natural y compenetrada.» Cfr. Windelband, Geschichte der neueren Philosophie, II: 224, y BosanQueT, The Philosophical Theory of the State, p. 244.

${ }^{36}$ Hegel, Philosophie des Rechts, parágrafo 258 (Suplemento): "pues esta esencia, sea o no sabida por el hombre, se realiza como una fuerza independiente en la que los individuos son sólo momentos. Es el camino de Dios en el mundo, que constituye el estado; su fundamento es la fuerza de la razón que se realiza como voluntad». Cfr. Ibid. parte 3. a, div. 3, p. 423. (Cfr. versión castellana cit., pp. 289-290.)

${ }^{37}$ Hegel, Philosophie des Rechts, parágrafo. 258. «El estado, en cuanto realidad de la voluntad substancial, realidad que ésta tiene en la autoconciencia particular elevada a su universalidad, es lo racional en y por sí.» (Cfr. versión castellana cit., p. 283.)

38 Windelband, Geschichte der neueren Philosophie, II:329.

39 Hegel, Philosophie des Rechts, parágrafo 158.

40 Ibid., parágrafo 151.

${ }^{41}$ Ibid., parágrafo 159. (Cfr. versión castellana cit., pp. 205-206.) 
forma de sociedad que Hegel denominó sociedad civil ${ }^{42}$. En la sociedad civil los individuos son conscientes de sus intereses particulares cuando éstos se encuentren en conflicto con los intereses de otros ${ }^{43}$. Los individuos llegan a ser entonces autoconscientes, y, cuando sus intereses particulares pasan al primer plano y se convierten en la fuerza determinante de su conciencia, surge una brecha entre el individuo y la colectividad, apareciendo ésta como algo externo y lejano para el individuo. Si encontráramos un consenso general entre los miembros de la sociedad civil éste aseguraría la forma de la «volonté de tous», porque "en la sociedad civil cada uno es su propio fin, y todos los demás no son nada para él $\aleph^{44}$.

Ahora bien, es característico de Hegel que apreciara la dignidad de estas formas de sociedad donde aparecen las diferencias individuales, y que las considerara como un momento esencial en el desarrollo de la voluntad general que encontramos en el estado ${ }^{45}$. Pues la voluntad general sólo adopta la forma autoconsciente de la razón dentro del estado ${ }^{46}$. Debido precisamente a que en el estado es donde la voluntad general reunirá la diversidad de elementos individuales que surgieron por primera vez en la sociedad civil, pueden éstos adoptar esa forma de la razón que consiste en la unidad de las diferencias ${ }^{47}$. No ocurre que «el interés del individuo en cuanto tal se ha transformado en el fin último», como ocurre en la sociedad civil; sino que, en lugar de esto, "la unión como tal es ella misma el fin y el contenido verdadero, y la determinación de los individuos es llevar una vida universal. Sus restantes satisfacciones, actividades y modos de comportarse tienen como punto de partida y resultado este elemento substancial y válido universalmente $»^{48}$.

La noción de voluntad general, tal como aparece perfeccionada en la filosofía del estado de Hegel, debe entenderse como una sustancia espiritual, que se manifiesta subjetivamente en la conciencia (Bewusstsein) individual en forma de conciencia moral (Gewissen), y objetivamente — haciéndose pública- en forma de hábito ético ${ }^{49}$. Tanto los fundamentos de la moralidad como los de

${ }^{42}$ Hegel, Philosophie des Rechts, parágrafos. 157, 184 y 238.

${ }^{43}$ Ibid., parágrafo 184.

${ }^{44}$ Ibid. parágrafo 182.

45 Ibid., parágrafo 187.

46 Ibid. parágrafo 258.

47 Ibid. (Nota de los trads.: en el texto original aparece dos veces la referencia a la nota 5 , aunque sólo hay una nota 5 al pie de página. Por esta razón este texto tiene una nota más que el original en este capítulo.)

${ }^{48}$ Hegel, Philosophie des Rechts, parágrafo 258, p. 284.

49 Bosanquet, The Philosophical Theory of the State, p. 93. "Nos encontramos con que la esencia de la sociedad humana consiste en un sí mismo, una vida y una voluntad comunes, que pertenecen a, y son ejercidos por, la sociedad como tal, o por los individuos en la sociedad como tal; da igual cómo lo digamos. Esta realidad de un sí mismo común en la acción del todo político recibe el nombre de "voluntad general"."

Ibid., p. 298: «Por tanto, en las instituciones tenemos aquel punto de encuentro de las mentes individuales que es la mente social. O digamos, más bien, que tenemos la sustancia ideal que, tomada como estructura universal, es lo social, pero que tomada en sus casos diferenciados es la mente individual.» Cfr. Windelband, «Vom Prinzip der Moral», Präludien, 1, p. 308. 
las leyes que se autoimpone la comunidad política se basan precisamente en esa sustancia espiritual.

La voluntad general debe entenderse finalmente como la síntesis de todo aquello que es valioso para el grupo social, ya se trate de la familia o del estado, en contraste con aquello que, en cada momento, opera sobre la colectividad en forma de impulsos ${ }^{50}$. La noción de la voluntad general en las obras de Hegel, y de otros autores anteriores y posteriores a él, no es básicamente sociológica, sino ético-jurídica ${ }^{51}$. Al intentar trasladar esta idea de la voluntad general a la socio-psicología encontramos uno de los muchos problemas controvertidos en el siglo pasado, porque la cuestión de la voluntad general y su relación con los individuos del grupo discurre en paralelo con el problema de la relación entre el alma y el cuerpo ${ }^{52}$.

Desde el punto de vista de este estudio, el problema es puramente epistemológico; es el problema de si la psicología debe considerarse como una ciencia puramente natural y fenoménica o no. En primera instancia, la voluntad general no debería de considerarse como un objeto de la socio-psicología, porque no es equiparable con ninguna de sus manifestaciones. Por otro lado, puesto que la voluntad general existe como un constructo histórico en la sociedad, habría que considerarla como producto y elemento determinante en el proceso empírico de la sociedad ${ }^{53}$.

Esta cuestión no la tenemos que responder aquí porque, en cualquier caso, la realidad de la voluntad general permanece intacta, y esto es suficiente para el propósito de este trabajo, que es definir los conceptos de «masa» y "público».

${ }^{50}$ Bosanquet, The Philosophical Theory of the State, p. 39. «Un sentimiento fuerte, como tal, es un mero hecho, una mera fuerza, y como tal lo considera el sociólogo; una ley implica la pretensión de ordenar lo que es justo, y esto es, por tanto, un sentimiento y algo más; dicho claramente: el punto de vista del bien social.»

KISTIAKOWSKI, Gesellschaft und Einzelwesen, p. 154. «En toda investigación sobre el proceso social es muy importante distinguir entre el espíritu general que conforma un todo o una colectividad con respecto a la cual los espíritus particulares se comportan como partes, y el espíritu general que domina como una norma o ley a todos los espíritus individuales y que se representa en la conciencia individual, a todos sus efectos, como un concepto general con un sentido determinado. La diferencia es ya clara por el hecho de que el orden ético-legal o las normas siempre permanecen iguales para todos los individuos que nacen en la misma sociedad, con independencia de su número; mientras que, por el contrario, el sentimiento o la voluntad patriótica o cualquier otro tipo de sentimiento social son sumamente dependientes, en su significado social y en su influjo, de la cantidad de individuos."

51 Windelband, «Normen und Naturgesetze», Präludien, 1. a ed., p. 176.

52 Windelband, Geschichte der Philosophie, pp. 516 y ss. y 529.

53 Münsterberg, Grundzüge der Psychologie, pp. 93 y 203. Windelband, "Normen und Naturgesetze», Präludien, 1.a ed., p. 246. 
Hemos llegado al final de este estudio y es necesario sintetizar lo más relevante de lo dicho sobre las nociones de masa y público.

Se ha visto que el concepto de interacción (simpatía o imitación) no es suficiente para una definición de la sociedad, ya que la interacción se produce también en «la guerra de todos contra todos» (el pánico). El concepto de sociedad implica que la gente que la compone forma una unidad más o menos permanente y que es capaz de actuar como tal. Cuando la sociedad se contempla como tal unidad, le aplicamos la categoría de sustancia. La pregunta es entonces: ¡en qué consiste la sustancia social?

La sustancia de la sociedad no podemos encontrarla en sus manifestaciones externas porque en la percepción de la sociedad no aparece acotada como tal fenómeno externo, ni se presenta como un todo homogéneo. La denominada «teoría orgánica» fue un intento de interpretar la sociedad como una unidad dada en la percepción, pero esta idea nunca se desarrolló con toda seriedad y siempre condujo a confusión. No obstante, esto no debería desanimarnos en el intento de concebir la sociedad como sustancia, pues en nuestra propia personalidad poseemos un estable plexo de cualidades al que atribuimos un significado sustancial aun cuando éste no nos venga dado como objeto en la percepción externa.

Aquello que llamamos personalidad se presenta exteriormente en forma de acciones; internamente, en cambio, en los impulsos e instintos. Sólo considerándolos como un todo conexo podemos llamar voluntad a estos impulsos e instintos. Por que la voluntad nunca se identifica con ellos tal como emergen en la conciencia, sino que, por el contrario, estos impulsos e instintos son manifestaciones de la voluntad.

Es posible hablar de una voluntad general en el mismo sentido. La voluntad general no se refiere simplemente a la interacción y recíproca determinación de las voluntades individuales, sino, más bien, a la existencia de una conexión duradera entre ellas, a través de la cual nos afanamos en ver en los hombres que se unen en diferentes momentos los mismos hombres y la misma sociedad.

La voluntad general, que se configura en primer término en los hábitos éticos, no debe considerarse como un tercer elemento, como algo aparte de las voluntades individuales, sino como aquello que es en ellas lo esencial. La voluntad general sólo se distingue de los impulsos e instintos de los diversos individuos particulares cuando es violada, es decir, cuando los impulsos o acciones del individuo se disponen contra ella. De esta manera el elemento ético-habitual (sittliche), que previamente se expresaba sólo como un impulso, emerge como una norma en la conciencia colectiva.

Los sentimientos y la conducta que se despiertan en la colectividad ante la acción de un individuo que es contraria a lo ético-habitual (unsittliche) deben entenderse, por ello, como expresión de la voluntad general, como una especie 
de evaluación de la acción ofensiva. En la conciencia del propio ofensor se producirá una evaluación similar de esa conducta que contradice los hábitos éticos, y que se expresa en los sentimientos de apuro, de vergüenza, de arrepentimiento, etc.; o en forma de juicio. A ese proceso de autoenjuiciamiento, tomado en su forma más clara, lo llamamos conciencia.

Tenemos que guardarnos de una doble equivocación. En primer lugar, la voluntad general no debe equipararse simplemente con el sentimiento y las ideas que dominan realmente a la colectividad en cada momento. Lo que llamamos voluntad general no es simplemente lo que opera en la conciencia colectiva como instinto y fuerza natural, sino lo que es válido para la colectividad. De ahí la distinción que hacemos entre "volonté de tous» y "volonté générale», entre la voluntad colectiva empírica y la normativa.

En segundo lugar, no se puede alimentar la opinión de que la conciencia colectiva que evalúa la acción inmoral está determinada solamente por los intereses personales e individuales. Si fuera así, el juicio de la colectividad tendría que expresarse de este modo: «Esta acción está en contradicción con nuestros intereses y, por tanto, es incorrecta». Por el contrario, cada juicio "naïf» sobre una acción — cuando se expresa en general- declara: "Esta acción no se corresponde con el hábito ético; por tanto, es mala». Sólo cuando se intenta justificar este juicio fundándolo en una visión sensualista del mundo se ve uno obligado a una interpretación individualista de tales acciones de la colectividad.

Para evitar las dificultades de explicar los juicios morales sobre una base sensualista-individualista se ha intentado explicarlos por medio de la simpatía. Se ha visto que el proceso de imitación simpatética es, en sí mismo, un proceso puramente formal, el modo en que los seres humanos somos capaces, en general, de sentir con los sentimientos de los otros; el único modo en que la vida interior de los otros puede ser un motivo de nuestra conducta. No obstante, el contenido de la conciencia de los individuos implicados sólo está parcialmente determinado por el proceso de interacción y no siempre es bienintencionado. El alegrarse con la desgracia ajena es tan producto del proceso de imitación simpatética como la compasión por su dolor. El hecho de que el sentido de la norma no esté determinado por los sentimientos simpatéticos se muestra en los actos que frecuentemente realizamos por compasión, aun sabiendo que no los debemos hacer. El hecho de que, pese a sentir con los otros sepamos hacer lo correcto, es lo que prueba que hay un elemento en nuestra conciencia que no lo determinan ni nuestras propias percepciones sensibles ni las percepciones sensibles de los otros reflejadas en nosotros mismos.

Carece igualmente de base la pretensión de que, incluso aunque la voluntad general no pudiera equipararse con la interacción simpatética de los sentimientos individuales, haya que considerarla genéticamente como producto de tal interacción. De nuevo, esto sólo es cierto en la medida en que la mutua asistencia y la compensación simpatéticas de los sentimientos individuales sea la condición previa para una acción colectiva, pues siempre ha sido la necesi- 
dad de una acción común para proteger los bienes comunes lo que ha producido el espíritu colectivo de los seres humanos.

La necesidad de una acción colectiva ha tenido también otros efectos. Cuando se produce una división dentro del grupo ésta fuerza a los individuos a examinar y valorar sus inclinaciones e intereses individuales con la vista puesta en los objetivos de la colectividad. Y es esa meta colectiva la que, una y otra vez, se afianza de tal forma en la voluntad general que no se limita simplemente a presentarse ante los hombres como un ideal, sino que, como fuerza interior, les inspira y les impulsa hacia adelante.

Las características psicológicas de los grupos sociales son:

(1) la interacción; es decir, el hecho de que los impulsos humanos se influyan y compensen recíprocamente; $y$

(2) una voluntad general que se manifiesta como un impulso colectivo que domina y reúne todos los impulsos individuales y que, ocasionalmente, se contrapone como norma a los sentimientos e impulsos individuales y transitorios de la colectividad.

La siguiente cuestión es: ¿cómo hay que distinguir los diversos tipos de formaciones grupales que nacen y se desvanecen entre los hombres de múltiples formas?

A pesar de su gran diversidad, este estudio divide, al compararlas en general, las formaciones grupales en dos clases. Primero está la de las sectas, castas, clases y grupos que sirven a algún propósito especial. Se trata de grupos muy diversos entre sí, que exigen una nueva clasificación interna. La única característica que tienen en común es que no están aislados, o que no existen solamente por sí mismos. La existencia de cada uno presupone la de otros grupos diferentes. Un partido político, por ejemplo, presupone la existencia de otros, sin los cuales sería inconcebible; y estos partidos se oponen de tal modo, que nadie podría ser miembro de dos al mismo tiempo.

Pero los partidos políticos, como todas las formaciones grupales que se han desarrollado en la sociedad para servir a tal o a cual interés especial o para realizar una función social, presuponen la existencia de una colectividad de la que son considerados como partes. Las metas a las que sirven y los impulsos que les mueven no son más que las manifestaciones particulares de una voluntad general que, por su parte, alcanza su expresión más plena en la organización política de un estado o en los cultos de un pueblo.

La masa y el público, los dos tipos de grupo que traemos aquí a consideración, se distinguen de todos los grupos anteriores. Son un tipo de unión social que se desarrolla a partir de los otros, yendo más allá de ellos, y que sirven para sacar a los individuos de los viejos vínculos y llevarlos a otros nuevos.

$\mathrm{Al}$ considerar en general esas formaciones sociales encontramos que la masa y el público difieren llamativamente de las otras. Se distinguen en que el elemento histórico, que desempeña un papel tan importante en los otros gru- 
pos, si no está en ellos completamente ausente, lo está, al menos, en gran parte. Lo que vemos en la masa y en el público son procesos a través de los cuales se forman nuevos grupos, aunque esos grupos no sean todavía conscientes de sí mismos. En una masa o en un público, los individuos carecen de una tradición común que les serviría de base para verse a sí mismos como una colectividad permanente. Por ejemplo: los hombres que se reúnen en una plaza pública conversan, intercambian opiniones, y luego se separan. Ocurre entonces, que el sentido íntimo del contacto personal y espiritual y los sentimientos e intereses que se habían suscitado y que les unieron por un momento se deshacen. Esta es la configuración más simple de una masa o de un público que cabe concebir.

Pero consideremos ahora el caso de cierto número de hombres que se reúnen frecuentemente y de modo regular. En este caso, se crea el estado de ánimo que haya dominado en el primer encuentro, en el segundo, en el tercero, en el cuarto, y así sucesivamente; y, de este modo, se configuran las costumbres y tradiciones. Un grupo formado de esa manera llega finalmente a ser consciente de su duración temporal y, por medio de este tomar conciencia de sí, se diferenciará más o menos de los demás hombres. La tradición de este modo formada proporcionará, precisamente, el material para una norma que deberá regular al grupo. La meta de ese proceso que veíamos empezar a funcionar en la configuración de la masa se alcanza cuando, finalmente, el grupo se clausura frente a los demás con objeto de preservar su tradición. Entonces, el grupo se cambia a sí mismo. La conciencia colectiva asume una forma normativa. Es decir, la voluntad del grupo, que antes funcionaba como un impulso colectivo dominador de los impulsos individuales, se perfecciona en forma de norma y regla.

Ahora ya podemos ver las relaciones que la masa y el público mantienen con los demás grupos sociales. En cuanto a su forma, es decir, considerados conceptualmente, la masa y el público preceden a los otros grupos, pero son, de hecho, posteriores: frecuentemente son las formas que los demás grupos adoptan al transformarse en una nueva totalidad que está aún por definir. Por lo demás, constituyen las formas mediante las que los individuos de otros grupos históricamente establecidos entran en nuevas vinculaciones. Por eso se reconoce que, cuando vemos a la masa y el público desarrollarse en la vida moderna, tienen como presupuesto la existencia previa de otros grupos donde han encontrado expresión funcional los múltiples y dispersos intereses de los hombres; y que, dondequiera y cuandoquiera que un nuevo interés se haga valer entre los ya existentes, allí se desarrolla inmediatamente una masa o un público a través de la unión de los grupos, o de determinados individuos de los grupos, para crear así una nueva forma social para los nuevos intereses. Vemos que en Europa se ha formado un grupo que va más allá de las fronteras de los estados y de las nacionalidades, y puede enunciarse la afirmación general de que, donde los intereses humanos - ya sean políticos o económicos- entren en conflicto e intenten conciliarse, siempre se desarrollará un público. Aún 
más: es precisamente este contacto y ajuste recíproco de las opiniones lo que desarrolla una tradición que supera las fronteras de los estados y de las nacionalidades, una tradición que contiene el núcleo de una norma y de una legislación de carácter internacional.

Por consiguiente, lo que distingue a la masa y al público de otros tipos de grupos es su forma y no el contenido de la conciencia colectiva. La masa y el público están dominados por un impulso colectivo, pero este tipo de voluntad colectiva aún no ha adoptado una forma normativa y, por tanto, hay que considerarla como una etapa empírica preliminar a la voluntad general y no identificarla con ésta concebida en el sentido histórico del término. Ni la masa ni el público se reconocen ellos mismos como un conjunto, ni tampoco tratan de determinar sus propias acciones. No existe en ellos ni regla, ni dominación consciente, ni autoconciencia alguna. La masa y el público se delimitan sólo por las condiciones de la interacción, y, por tanto, no pueden delimitarse a sí mismos como lo hacen otros grupos. Por ejemplo, la admisión en un club gastronómico normal está ligada siempre a ciertas formalidades con las que el nuevo miembro se obliga virtualmente a adaptarse al ambiente y a conservar la tradición existente.

En este aspecto masa y público se parecen. Su diferencia se basa en las condiciones bajo las cuales se desarrollan. El ingreso en la masa depende de las condiciones más simples que puedan imaginarse. Concretamente, basta con tener la capacidad de sentir y de sentir con otros. Por supuesto que, incluso en estas condiciones, se produce elección y selección, pero de un modo puramente psicológico del que el propio individuo no es consciente. Aquí también hay dominación, pero es puramente psicológica y no normativa. El individuo experimenta la voluntad colectiva como su propio impulso interior. Las condiciones bajo las que uno entra en un público son algo más exigentes. No sólo se requiere la capacidad de sentir y sentir-con, sino también la de pensar y pensar con los otros. Esto no significa que uno esté forzado a doblegarse a cualquier regla práctica, sólo que tiene que subordinarse incondicionalmente a las reglas de la lógica.

Hay aún otra diferencia entre masa y público: el público es crítico. Dentro del público las opiniones están divididas. Cuando el público deja de ser crítico, se disuelve o se transforma en una masa. Precisamente ahí reside la característica esencial que distingue a una masa de un público: la masa se somete a la presión de un impulso colectivo al que obedece sin crítica alguna. El público, por el contrario - precisamente porque se compone de individuos con opiniones diferentes - se guía por la previsión y la deliberación racional. Sin embargo, no puede ignorarse que, como la masa, el público está también, hasta cierto punto, bajo la presión del impulso colectivo, y lo está aun cuando, en este caso, el impulso colectivo haya encontrado expresión individual en los diversos partidos o individuos. Denominamos "opinión pública» a esa visión que se logra por medio de la crítica y al consiguiente efecto de ilustración del impulso colectivo que dominan sobre un público. 
Si se intenta definir masa y público de acuerdo con la forma en que se ejerce la dominación, resulta claro que, hablando propiamente, la masa y el público son las formas de sociedad que se pueden designar como individualistas. Y, una vez más, hay que reconocer en este caso otra diferencia entre masa y público. Sólo en la masa existe la anarquía en su forma más pura. Como miembros del público las gentes están, al menos, bajo el dominio de las normas de la lógica, pues, como ha advertido ya Max Stirner, la última tiranía es la del concepto.

Aunque la masa y el público se distinguen porque en la primera domina el instinto y en el segundo prevalece la razón, no hay que pasar por alto, sin embargo, un punto: que esta distinción se refiere sólo a la forma de la conciencia colectiva y no a su contenido. Esta distinción es, por supuesto, puramente lógica y no puede considerarse como una diferencia valorativa.

Por último, hay que subrayar la diferencia decisiva entre masa y público: en la masa, tanto la norma teórica como la práctica están conjuntamente contenidas, de modo implícito, en el impulso colectivo, mientras que, en el público - precisamente porque los individuos tienen opiniones diferentes-, esas dos normas se separan. En este caso, los individuos están dominados por la norma teórica, incluso cuando la norma práctica se erija ante ellos como un ideal solamente alcanzable a través de la acción y la discusión.

Traducción del alemán de Ignacio SÁNCHEZ DE LA YNCERA y Esteban LÓPEZ-ESCOBAR 


\section{CRITICA DE LIBROS}

